\title{
Analyses of temperature and precipitation in the Indian Jammu and Kashmir region for the 1980-2016 period: implications for remote influence and extreme events
}

\author{
Sumira Nazir Zaz ${ }^{1}$, Shakil Ahmad Romshoo ${ }^{1}$, Ramkumar Thokuluwa Krishnamoorthy ${ }^{2}$, and \\ Yesubabu Viswanadhapalli ${ }^{2}$ \\ ${ }^{1}$ Department of Earth Sciences, University of Kashmir, Hazratbal, Srinagar, Jammu and Kashmir 190006, India \\ ${ }^{2}$ National Atmospheric Research Laboratory, Dept. of Space, Govt. of India, Gadanki, Andhra Pradesh 517112, India
}

Correspondence: Ramkumar Thokuluwa Krishnamoorthy (tkram@narl.gov.in)

Received: 23 February 2018 - Discussion started: 22 May 2018

Revised: 19 November 2018 - Accepted: 26 November 2018 - Published: 2 January 2019

\begin{abstract}
The local weather and climate of the Himalayas are sensitive and interlinked with global-scale changes in climate, as the hydrology of this region is mainly governed by snow and glaciers. There are clear and strong indicators of climate change reported for the Himalayas, particularly the Jammu and Kashmir region situated in the western Himalayas. In this study, using observational data, detailed characteristics of long- and short-term as well as localized variations in temperature and precipitation are analyzed for these six meteorological stations, namely, Gulmarg, Pahalgam, Kokarnag, Qazigund, Kupwara and Srinagar during 1980-2016. All of these stations are located in Jammu and Kashmir, India. In addition to analysis of stations observations, we also utilized the dynamical downscaled simulations of WRF model and ERA-Interim (ERA-I) data for the study period. The annual and seasonal temperature and precipitation changes were analyzed by carrying out Mann-Kendall, linear regression, cumulative deviation and Student's $t$ statistical tests. The results show an increase of $0.8^{\circ} \mathrm{C}$ in average annual temperature over 37 years (from 1980 to 2016) with higher increase in maximum temperature $\left(0.97^{\circ} \mathrm{C}\right)$ compared to minimum temperature $\left(0.76^{\circ} \mathrm{C}\right)$. Analyses of annual mean temperature at all the stations reveal that the high-altitude stations of Pahalgam $\left(1.13^{\circ} \mathrm{C}\right)$ and Gulmarg $\left(1.04^{\circ} \mathrm{C}\right)$ exhibit a steep increase and statistically significant trends. The overall precipitation and temperature patterns in the valley show significant decreases and increases in the annual rainfall and temperature respectively. Seasonal analyses show significant increasing trends in the winter and spring temperatures at all stations, with prominent
\end{abstract}

decreases in spring precipitation. In the present study, the observed long-term trends in temperature $\left({ }^{\circ} \mathrm{Cyear}^{-1}\right)$ and precipitation $\left(\mathrm{mm} \mathrm{year}^{-1}\right)$ along with their respective standard errors during 1980-2016 are as follows: (i) 0.05 (0.01) and -16.7 (6.3) for Gulmarg, (ii) 0.04 (0.01) and -6.6 (2.9) for Srinagar, (iii) 0.04 (0.01) and -0.69 (4.79) for Kokarnag, (iv) 0.04 (0.01) and -0.13 (3.95) for Pahalgam, (v) 0.034 (0.01) and -5.5 (3.6) for Kupwara, and (vi) 0.01 (0.01) and -7.96 (4.5) for Qazigund. The present study also reveals that variation in temperature and precipitation during winter (December-March) has a close association with the North Atlantic Oscillation (NAO). Further, the observed temperature data (monthly averaged data for 1980-2016) at all the stations show a good correlation of 0.86 with the results of WRF and therefore the model downscaled simulations are considered a valid scientific tool for the studies of climate change in this region. Though the correlation between WRF model and observed precipitation is significantly strong, the WRF model significantly underestimates the rainfall amount, which necessitates the need for the sensitivity study of the model using the various microphysical parameterization schemes. The potential vorticities in the upper troposphere are obtained from ERA-I over the Jammu and Kashmir region and indicate that the extreme weather event of September 2014 occurred due to breaking of intense atmospheric Rossby wave activity over Kashmir. As the wave could transport a large amount of water vapor from both the Bay of Bengal and Arabian Sea and dump them over the Kashmir region through wave breaking, it probably resulted in the historical devastating flooding of the whole Kashmir 
valley in the first week of September 2014. This was accompanied by extreme rainfall events measuring more than $620 \mathrm{~mm}$ in some parts of the Pir Panjal range in the south Kashmir.

\section{Introduction}

Climate change is a phenomenon affecting the Earth's atmosphere and surface which has in recent decades been shown to have significant effects on all spheres of life almost everywhere in the world. Extreme weather events like anomalously large floods and unusual drought conditions associated with changes in climate play havoc with livelihoods of citizens even of developed societies, particularly in coastal and mountainous areas. Jammu and Kashmir, India, located in the western Himalayan region, is one such cataclysmically formed mountainous region where the significant influence of climate change on local weather has been observed for the last few decades: (1) shrinking and reducing glaciers, (2) devastating floods, (3) decreasing winter duration and rainfall, and (4) increasing summer duration and temperature (Solomon et al., 2007; Kohler and Maselli, 2009; Immerzeel et al., 2010; Romshoo et al., 2015, 2017). Western disturbances (WDs) are considered one of the main sources of winter precipitation for the Jammu and Kashmir region, which brings water vapor mainly from the tropical Atlantic Ocean, Mediterranean Sea, Caspian Sea and Black Sea. Though WD is perennial, it is most intense during northern winter (December-February). Planetary-scale atmospheric Rossby waves (RWs) have the potential to significantly alter the distribution and movement of WD according to their intensity and duration (from a few to tens of days). Since WD is controlled by planetary-scale Rossby waves in the whole troposphere of the subtropical region, diagnosing different kinds of precipitation characteristics is easier with the help of potential vorticity $(\mathrm{PV})$ at $350 \mathrm{~K}$ potential temperature $(\mathrm{PT})$ and $200 \mathrm{hPa}$ pressure surface (PS) as they are considered proxies for Rossby wave activities (Ertel, 1942; Bartels et al., 1998; Hunt et al., 2018a). Henceforth, it will be simply called PV at $350 \mathrm{~K}$ and $200 \mathrm{hPa}$ surfaces. For example, Postel and Hitchman (1999) and Hunt et al. (2018b) studied the characteristics of Rossby wave breaking (RWB) events occurring at $350 \mathrm{~K}$ surfaces transecting the subtropical westerly jets. Similarly, Waugh and Polvani (2000) studied RWB characteristics at $350 \mathrm{~K}$ surfaces in the Pacific region during northern fall-spring, with an emphasis on their influence on westerly ducts and their intrusion into the tropics. Since PV is a conserved quantity on isentropic and isobaric surfaces when there is no exchange of heat and pressure respectively, it is widely used for investigating large-scale dynamical processes associated with frictionless and adiabatic flows. Moreover, all other dynamical parameters, under a given suitable balanced-atmospheric-background condition, can be derived from PV and boundary conditions (Hoskins et al., 1985).

Divergence of the atmospheric air flows near the upper troposphere is larger during precipitation, leading to increases in the strength of PV. Because of this, generally there will be a good positive correlation between variations in the strength of PV in the upper troposphere and precipitation over the ground, provided that the precipitation is mainly due to the passage of large-scale atmospheric weather systems like western disturbances and monsoons. Wind flows over topography can significantly affect the vertical distribution of water vapor and precipitation characteristics. Because of this, positive correlation between variations in PV and precipitation can be modified significantly. These facts need to be taken into account while finding long-term variations in precipitation near mountainous regions like the western Himalaya. The interplay between the flow of western disturbances and topography of the western Himalaya complicates further the identification of source mechanisms of extreme weather events (Das et al., 2002; Shekhar et al., 2010) like the ones that occurred in the western Himalayan region: Kashmir floods in 2014, Leh floods in 2010 in the Jammu and Kashmir region, and Uttrakhand floods in 2013. Kumar et al. (2015) also noted that major flood events in the Himalayas are related to changing precipitation intensity in the region. This necessitates making use of proper surrogate parameters like PV and distinguishing between different source mechanisms of extreme weather events associated with both the long-term climatic impacts of remote origin and shortterm localized ones like organized convection (Romatschke and Houze, 2011; Rasmussen and Houze, 2012; Rasmussen and Houze Jr., 2016; Martius et al., 2012).

The main aim of the present study is to investigate longterm (climate) variation in surface temperature and precipitation over the Jammu and Kashmir region (western Himalayas) of India in terms of its connections with NAO and atmospheric Rossby wave activity in the upper troposphere. Since PV is considered a measure of Rossby wave activity, the present work analyses in detail, for a period of 37 years during 1980-2016, monthly variation in PV (ERA-interim reanalysis data, Dee et al., 2001) in the upper troposphere (at $350 \mathrm{~K}$ and $200 \mathrm{hPa}$ surfaces) and compares it with observed surface temperature and rainfall (India Meteorological Department, IMD) at six widely separated mountainous locations with variable orographic features (Srinagar, Gulmarg, Pahalgam, Qazigund, Kokarnag and Kupwara). There exist several reports on climatological variation in meteorological parameters in various parts of the Himalayas. For example, Kumar and Jain (2010) and Bhutiyani et al. (2010) found an increase in the temperature in the north-western Himalayas with significant variations in precipitation patterns. Archer and Fowler (2004) examined temperature data of seven stations in the Karakoram and Hindu Kush mountains of the Upper Indus River Basin (UIRB) in search of seasonal and annual trends using statistical tests like regres- 


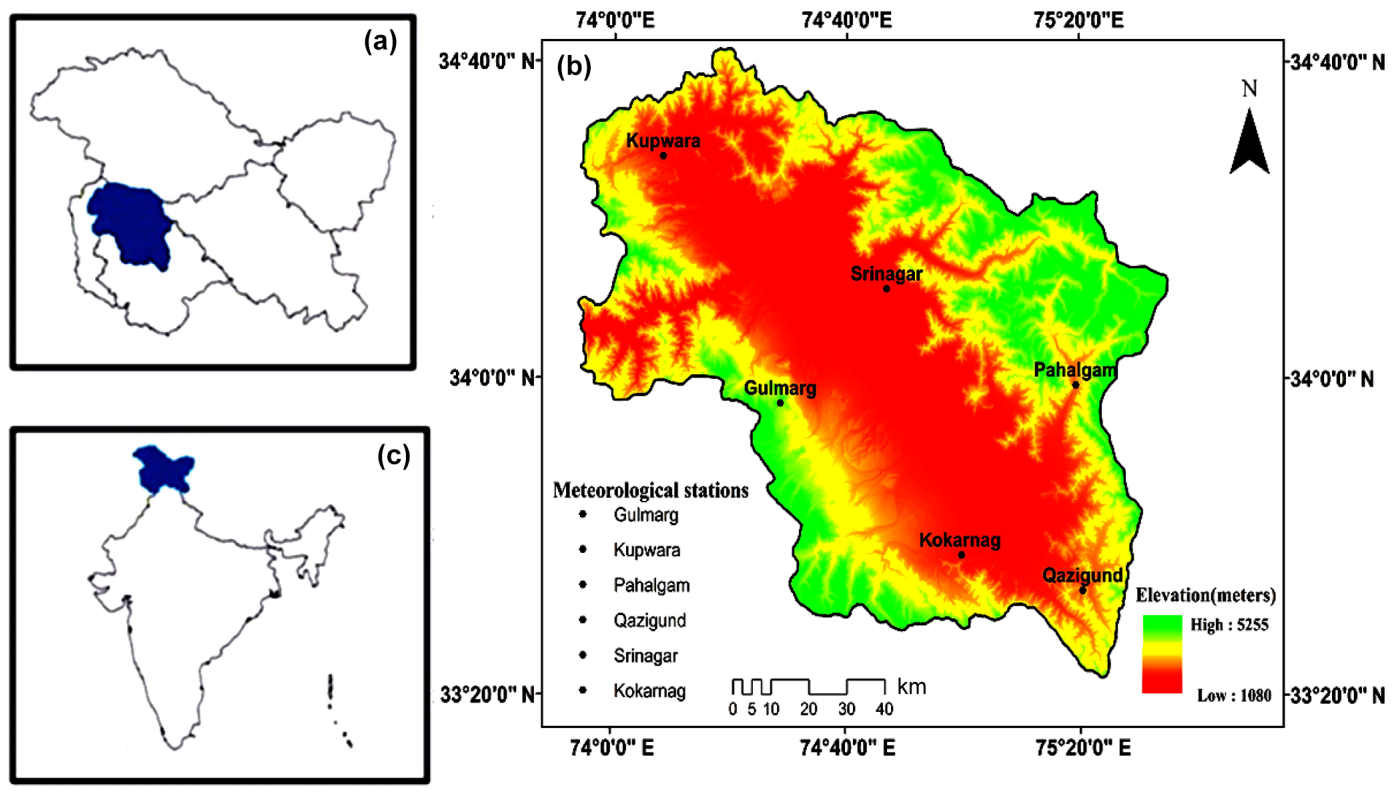

Figure 1. Geographical setting of the Kashmir valley (b) inside the Jammu and Kashmir state (a) of India (c) along with marked locations of six meteorological observation stations: Srinagar, Gulmarg, Pahalgam, Kokarnag, Qazigund and Kupwara.

sion analysis. Their results revealed that mean winter maximum temperature has increased significantly while mean summer minimum temperature declined consistently. On the contrary, Liu et al. (2009) examined long-term trends in minimum and maximum temperatures over the Tibetan mountain range during 1961-2003 and found that minimum temperature increases faster than maximum temperature in all months. Romshoo et al. (2015) observed changes in snow precipitation and snowmelt runoff in the Kashmir valley and attributed the observed depletion of stream flow to the changing climate in the region. Bolch et al. (2012) reported that the glacier extent in the Karakoram mountain range is increasing.

These contrasting findings of long-term variations in temperature and precipitation in the Himalayas need to be verified by analyzing long-term climatological data available in the region. However, the sparse and scanty availability of regional climate data pose challenges in understanding the complex microclimate in this region. Therefore, studying the relationship of recorded regional (Jammu and Kashmir) climatic variations in temperature and precipitation with remote and large-scale weather phenomena such as the NAO and El Niño Southern Oscillation (ENSO) is necessary for understanding the physical processes that control the locally observed variations (Ghasemi, 2015). Archer and Fowler (2004) and Iqbal and Kashif (2013) found that large-scale atmospheric circulation like NAO significantly influences the climate of the Himalayas. However, detailed information about the variation in temperature and precipitation and its teleconnection with observed variations in NAO is inadequately available for this part of the Himalayan region (Kashmir Valley).

\section{Geographical setting of Kashmir}

The mountainous valley of Kashmir has a unique geographical setting and it is located between the Greater Himalayas in the north and Pir Panjal range in the south, roughly within the latitude and longitude ranges of $33^{\circ} 55^{\prime}$ to $34^{\circ} 50^{\prime} \mathrm{N}$ and $74^{\circ} 30^{\prime}$ to $75^{\circ} 35^{\prime} \mathrm{E}$ respectively (Fig. 1). The heights of these mountains range from about 3000 to $5000 \mathrm{~m}$ and the mountains strongly influence the weather and climate of the region. Generally the topographic setting of the six stations, though variable, could be broadly categorized into two groups: (1) stations located on plains (Srinagar, Kokarnag, Qazigund and even Kupwara) and (2) those located in the mountain setting (Gulmarg, Pahalgam). Physiographically, the valley of Kashmir is divided into three regions: the Jhelum valley floor, Greater Himalayas and Pir Panjal. In order to represent all the regions of the valley, six meteorological stations located widely with different mean sea levels (m.s.l.), namely, Gulmarg (2740 m), Pahalgam (2600 m), Kokarnag (2000 m), Srinagar (1600 m), Kupwara (1670 m) and Qazigund $(1650 \mathrm{~m})$, were selected for analyses of observed weather parameters.

The Kashmir valley is one of the important watersheds of the upper Indus basin, harboring more than 105 glaciers, and it experiences the mediterranean type of climate with marked seasonality (Romshoo and Rashid, 2014). Broadly, four seasons (Khattak et al., 2011; Rashid et al., 2015) are defined for the Kashmir valley: winter (December to February), spring (March to May), summer (June to August) and autumn (September to November). It is to be clarified here that while defining the period of NAO (Fig. 4) considered 
December-March to be winter months as defined by Archer and Fowler (2004) and Iqbal and Kashif (2013) and in all other parts of the paper it is December-February as per the IMD definition. The annual temperature in the valley varies from about -10 to $35^{\circ} \mathrm{C}$. The rainfall pattern in the valley is dominated by wintertime precipitation associated with western disturbances (Dar et al., 2014) while the snow precipitation is received mainly in winter and early spring (Kaul and Qadri, 1979).

\section{Data and methodology}

The India Meteorological Department provided 37 years (1980-2016) of data of daily precipitation, maximum and minimum temperatures for all six stations. Monthly averaged data were further analyzed to find long-term variations in weather parameters. Statistical tests including MannKendall, Spearman's rho, cumulative deviation and Student's $t$ test were performed to determine long-term trends and turning points of weather parameters with statistical significance. Similar analyses and tests were also performed for the Weather and Research Forecasting (WRF) model-simulated and ERA-Interim reanalysis data $\left(0.75^{\circ}\right.$ by $0.75^{\circ}$ spatial resolution in the horizontal plane, monthly averaged time resolution) of same weather parameters and for the NAO index. A brief description of these data sets is provided below.

\subsection{Measurements and model simulations}

The obtained observational data are analyzed carefully for homogeneity and missing values. Analyses of ratios of temperature from the neighboring stations with the Srinagar station were conducted using a relative homogeneity test (World Meteorological Organization, 1970). It is found that there is no significant inhomogeneity and data gap for any station. Few missing data points were linearly interpolated and enough care was taken not to make any meaningful interpretation during such short periods of data gaps in the observations. Annual and seasonal means of temperature and precipitation were calculated for all the stations and years. To compute seasonal means, the data were divided into the following seasons: winter (December to February), spring (March to May), summer (June to August) and autumn (September to November). Trends in the annual and seasonal means of temperature and precipitation were determined using Mann-Kendall (nonparametric test) and linear regression tests (parametric test) at the confidence levels of $S=99 \%$ or (0.01), $S=95 \%$ or 0.05 and $S=90 \%$ or 0.1 . These tests have been extensively used in hydrometeorological data analyses as they are less sensitive to heterogeneity of data distribution and least affected by extreme values or outliers in data series. Various methods have been applied to determine change points of a time series (Radziejewski et al., 2000; Chen and Gupta, 2012). In this study, a change point in time series of temperature and precipitation was identified using cumulative deviation test and Student's $t$ test (Pettitt, 1979). This method detects the time of significant change in the mean of a time series when the exact time of the change is unknown (Gao et al., 2011).

Winter NAO index during 1980-2010 were obtained for further analyses from Climatic Research Unit through the web link https://www.cru.uea.ac.uk/data, last access: 17 December 2018. The winter (December-March) NAO index is based on difference of normalized sea level pressure (SLP) between Lisbon, Portugal and Iceland, which is available from 1964 onwards. Positive NAO index is associated with stronger-than-average westerlies over the middle latitudes (Hurrell and van Loon, 1997). The correlation between mean (December-March) temperature, precipitation and NAO index was determined using the Pearson correlation coefficient method. To test whether the observed trends in winter temperature and precipitation are enforced by NAO, linear regression analysis (forecast) was performed (Fig. 4e and f). The following algorithm calculates or predicts a future value by using existing values. The predicted value is a $y$ value for a given $w$ value. The known values are existing $w$ values and $y$ values, and the new value is predicted by using linear regression.

The syntax is as follows:

FORECAST $(x$, known_y's, known_w's $)$.

$W$ is the data point for which we want to predict a value. Known_y's is the dependent array or range of data (rainfall or temperature), and Known_w's is the independent array or range of data (time).

The equation for FORECAST is $a+b w$, where

$a=\hat{y}-b \hat{w}$ and $b=\sum(w-\hat{w})(y-\hat{y}) / \sum(w-\hat{w})^{2}$

and where $\hat{w}$ and $\hat{y}$ are the sample means AVERAGE (known_w's) and AVERAGE (known y's).

\subsection{WRF model configuration}

The Advanced Research WRF version 3.9.1 model simulation was used in this study to downscale the ERA-Interim (European Centre for Medium-Range Weather Forecasts reanalysis) data over the Indian monsoon region. The model is configured with 2 two-way nested domains (18 and $9 \mathrm{~km}$ horizontal resolutions), 51 vertical levels and model top at $10 \mathrm{hPa}$ level. The model first domain extends from $24.8516^{\circ}$ to $115.148^{\circ}$ longitude and from -22.1127 to $46.7629^{\circ}$ latitude while the second domain covers from $56.3838^{\circ}$ to $98.5722^{\circ}$ longitude and from -3.86047 to $38.2874^{\circ}$ latitude.

The initial and boundary conditions supplied to the WRF model are obtained from ERA-Interim 6-hourly data. The model physics used in the study for boundary layer processes is Yonsei University's nonlocal diffusion scheme (Hong et al., 2006), the Kain-Fritsch scheme for cumulus convec- 

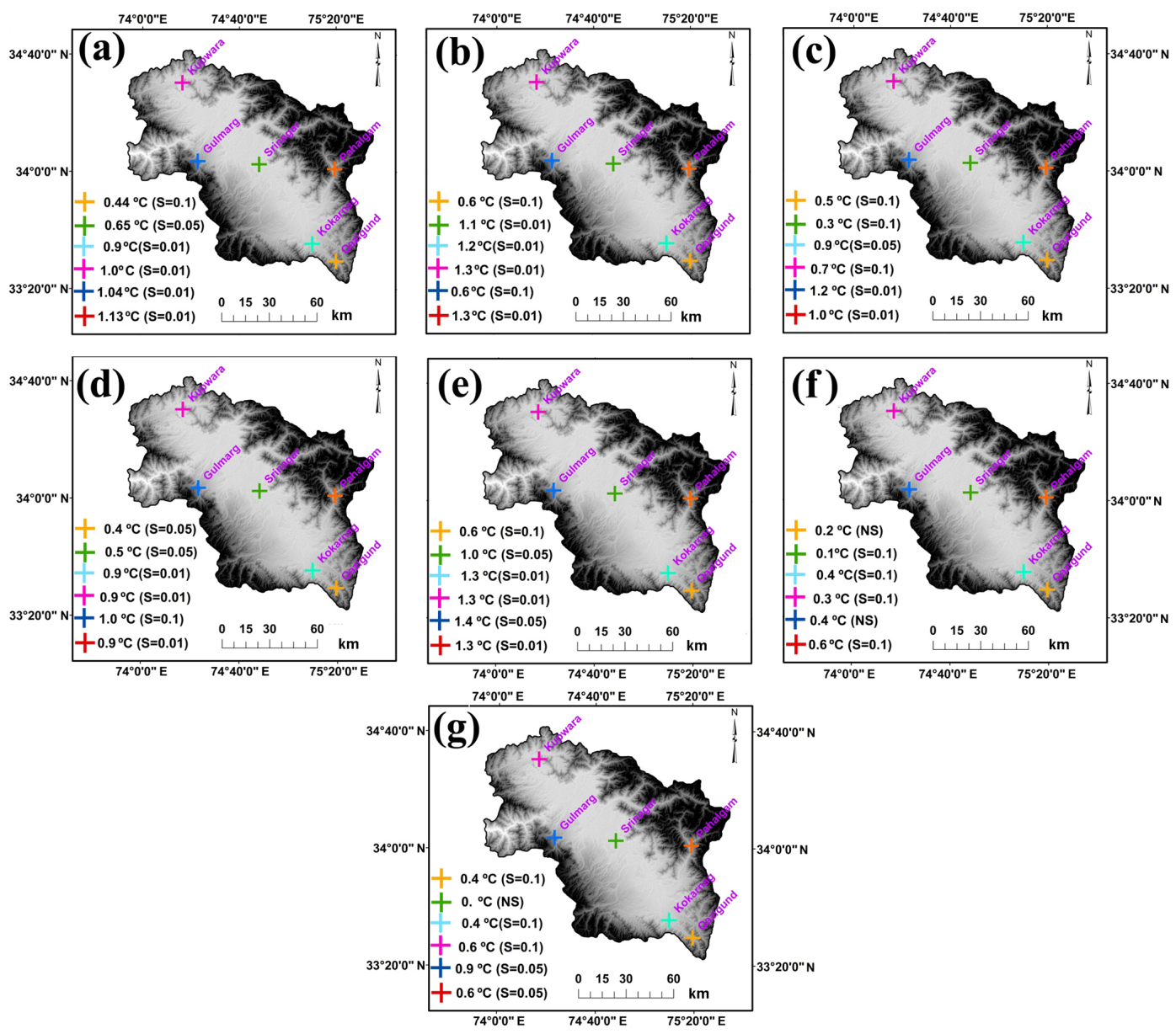

Figure 2. Trends in surface temperature $\left({ }^{\circ} \mathrm{C}\right)$ at the six interested locations of the Kashmir valley (a) for annual mean temperature, (b) maximum temperature, $(\mathbf{c})$ minimum temperature, $(\mathbf{d})$ winter mean temperature during December-February, (e) spring mean temperature (MarchMay), (f) summer mean temperature (June-August) and (g) autumn mean temperature (September-November).

tion (Kain and Fritsch, 1993), Thomson scheme for microphysical processes, the Noah land surface scheme (Chen and Dudhia, 2001) for surface processes, Rapid Radiation Transfer Model (RRTM) for long-wave radiation (Mlawer et al., 1997), and the Dudhia (1989) scheme for short-wave radiation. The physics options configured in this study are adopted based on the previous studies of heavy rainfall and monsoon studies over the Indian region (Srinivas et al., 2013, 2018; Madala et al., 2014; Priyanka et al., 2016).

For the present study, the WRF model is initialized on a daily basis at 12:00 UTC using ERA-Interim data and integrated for a $36 \mathrm{~h}$ period using the continuous re-initialization method (Lo et al., 2008; Langodan et al., 2016; Viswanadhapalli et al., 2017). Keeping the first $12 \mathrm{~h}$ as model spin-up time, the remaining $24 \mathrm{~h}$ daily simulations of the model are merged to get the data during 1980-2016. To find out the skill of the model, the downscaled simulations of the WRF model are validated for six IMD surface meteorological stations. The statistical skill scores such as bias, mean error (ME) and root mean square error (RMSE) were computed for the sim- ulated temperature against the observed temperature data of IMD.

\section{Results and discussion}

\subsection{Trend in annual and seasonal temperature}

Tables 1 and 2 show the results of statistical tests (MannKendall and linear regression, cumulative deviation and Student's $t$ ) carried out on the temperature and precipitation data respectively. All the parametric and nonparametric tests carried out for the trend analysis and abrupt changes in the trend showed almost similar results. Table 1 therefore shows results of representative tests where higher values of statistical significance between Mann-Kendall-linear regression test and cumulative deviation-Student's $t$ test are considered. It is evident that there is an increasing trend at different confidence levels in annual and seasonal temperatures of all six stations (Pahalgam, Gulmarg, Kokar- 
Table 1. Annual and seasonal temperature trends in the Kashmir Valley during 1980-2016.

\begin{tabular}{llllllllll}
\hline $\begin{array}{l}\text { Stations } \\
\text { (Mann-Kendall test) }\end{array}$ & Temperature trends & Annual & Min & Max & Winter & Spring & Summer & $\begin{array}{l}\text { Autumn } \\
\begin{array}{c}\text { Abrupt change } \\
\text { (Student's } t \text { test) }\end{array}\end{array}$ \\
\hline Gulmarg & Increasing trend & $S=0.01$ & $\begin{array}{l}S=0.01 \\
Z \text { statistics }\end{array}$ & $\begin{array}{l}3.976 \\
3.059\end{array}$ & $\begin{array}{l}S=0.1 \\
1.564\end{array}$ & $\begin{array}{l}S=0.05 \\
2.43\end{array}$ & $\begin{array}{l}S=0.01 \\
2.806\end{array}$ & $\begin{array}{l}\text { NS } \\
0.486\end{array}$ & $\begin{array}{l}S=0.05 \\
2.159\end{array}$ \\
\hline Pahalgam & Increasing trend & $S=0.01$ & $S=0.01$ & $S=0.01$ & $S=0.01$ & $S=0.01$ & $\begin{array}{l}S=0.1 \\
1.71\end{array}$ & $\begin{array}{l}S=0.05 \\
2.416\end{array}$ \\
& $Z$ statistics & 4.119 & 3.6 & 3.519 & 3.118 & 3.438 & 1995 \\
\hline Srinagar & Increasing trend & $S=0.05$ & $S=0.1$ & $S=0.01$ & $S=0.05$ & $S=0.05$ & $S=0.1$ & NS \\
& $Z$ statistics & 2.108 & 1.392 & 2.804 & 1.992 & 2.413 & 0.374 & 0.198 \\
\hline Kupwara & Increasing trend & $S=0.01$ & $S=0.1$ & $S=0.01$ & $S=0.05$ & $S=0.01$ & $S=0.1$ & $S=0.1$ \\
& $Z$ statistics & 3.433 & 1.819 & 3.246 & 1.988 & 2.719 & 1.78 & 1.865 \\
\hline Kokarnag & Increasing trend & $S=0.01$ & $S=0.05$ & $S=0.01$ & $S=0.01$ & $S=0.01$ & $S=0.1$ & $S=0.1$ \\
& $Z$ statistics & 3.467 & 2.363 & 3.11 & 3.195 & 3.195 & 1.46 & 0.68 \\
\hline Qazigund & Increasing trend & $S=0.1$ & $S=0.1$ & $S=0.1$ & $S=0.05$ & $S=0.05$ & NS & $S=0.1$ \\
& $Z$ statistics & 1.717 & 1.77 & 1.68 & 2.026 & 2.236 & -0.714 & -1.501 \\
\hline
\end{tabular}

${ }^{a}$ Critical values: $a=0.10(1.654) ; a=0.05(1.96) ; a=0.01(2.567)$.

Table 2. Annual and seasonal precipitation trends in Kashmir valley during 1980-2016.

\begin{tabular}{|c|c|c|c|c|c|c|c|}
\hline $\begin{array}{l}\text { Stations }^{\mathrm{a}} \\
\text { (Mann-Kendall test) }\end{array}$ & Precipitation trends & Annual & Winter & Spring & Summer & Autumn & $\begin{array}{l}\text { Abrupt change } \\
\text { (Student's } t \text { test) }\end{array}$ \\
\hline Gulmarg & $\begin{array}{l}\text { Decreasing trend } \\
Z \text { statistics }\end{array}$ & $\begin{array}{l}S=0.05 \\
-1.988\end{array}$ & $\begin{array}{l}S=0.1 \\
-1.53\end{array}$ & $\begin{array}{l}S=0.01 \\
-2.515\end{array}$ & $\begin{array}{l}\mathrm{NS} \\
-0.445\end{array}$ & $\begin{array}{l}\text { NS } \\
-0.394\end{array}$ & 1995 \\
\hline Pahalgam & $\begin{array}{l}\text { Decreasing trend } \\
Z \text { statistics }\end{array}$ & $\begin{array}{l}S=0.1 \\
-1.442\end{array}$ & $\begin{array}{l}S=0.1 \\
-1.136\end{array}$ & $\begin{array}{l}S=0.05 \\
-2.151\end{array}$ & $\begin{array}{l}\text { NS } \\
-0.556\end{array}$ & $\begin{array}{l}\text { NS } \\
0.034\end{array}$ & 1995 \\
\hline Srinagar & $\begin{array}{l}\text { Decreasing trend } \\
Z \text { statistics }\end{array}$ & $\begin{array}{l}S=0.05 \\
-2.532\end{array}$ & $\begin{array}{l}\text { NS } \\
0.051\end{array}$ & $\begin{array}{l}S=0.01 \\
-2.060\end{array}$ & $\begin{array}{l}\mathrm{NS} \\
-0.105\end{array}$ & $\begin{array}{l}\text { NS } \\
-1.003\end{array}$ & 1995 \\
\hline Kupwara & $\begin{array}{l}\text { Decreasing trend } \\
Z \text { statistics }\end{array}$ & $\begin{array}{l}S=0.1 \\
-1.962\end{array}$ & $\begin{array}{l}S=0.1 \\
-0.817\end{array}$ & $\begin{array}{l}S=0.01 \\
-2.919\end{array}$ & $\begin{array}{l}\text { NS } \\
-0.986\end{array}$ & $\begin{array}{l}\text { NS } \\
-0.153\end{array}$ & 1995 \\
\hline Kokarnag & $\begin{array}{l}\text { Decreasing trend } \\
Z \text { statistics }\end{array}$ & $\begin{array}{l}S=0.1 \\
-1.326\end{array}$ & $\begin{array}{l}S=0.1 \\
-1.53\end{array}$ & $\begin{array}{l}S=0.05 \\
-2.276\end{array}$ & $\begin{array}{l}\text { NS } \\
0.186\end{array}$ & $\begin{array}{l}\text { NS } \\
-0.119\end{array}$ & 1995 \\
\hline Qazigund & $\begin{array}{l}\text { Decreasing trend } \\
Z \text { statistics }\end{array}$ & $\begin{array}{l}S=0.05 \\
-1.275\end{array}$ & $\begin{array}{l}\text { NS } \\
-0.764\end{array}$ & $\begin{array}{l}S=0.05 \\
-2.413\end{array}$ & $\begin{array}{l}\mathrm{NS} \\
0.359\end{array}$ & $\begin{array}{l}\text { NS } \\
-0.232\end{array}$ & 1995 \\
\hline
\end{tabular}

${ }^{\mathrm{a}}$ Critical values: $a=0.10(1.654) ; a=0.05(1.96) ; a=0.01(2.567)$

nag, Srinagar, Kupwara and Qazigund), located in different topographical settings (Table 3). During 1980-2016, Pahalgam and Gulmarg, located at higher elevations of about $2500 \mathrm{~m}$ a.m.s.l. (above mean sea level), registered statistically significant increases in average annual temperature by 1.13 and $1.04{ }^{\circ} \mathrm{C}$ (Fig. 2a). It should be noted that hereafter the period 1980-2016 will not be mentioned explicitly, and statistically significant means the confidence level is about $90 \%$. Kokarnag and Kupwara, located at the heights of about 1800-2000 m a.m.s.l., showed increases of 0.9 and $1{ }^{\circ} \mathrm{C}$ respectively (Fig. 2a). However, Srinagar and Qazigund, located at the heights of about 1700-1600 m a.m.s.l., exhibited increases of 0.65 and $0.44^{\circ} \mathrm{C}$ (Fig. 2a).
Analyses of maximum and minimum temperatures (Table 1 and Fig. 2b) for the six stations reveal a higher rate of increase in maximum temperature. Pahalgam and Kupwara recorded the highest rise of $\sim 1.3{ }^{\circ} \mathrm{C}$, followed by Kokarnag $\left(1.2^{\circ} \mathrm{C}\right)$ and Srinagar $\left(1.1^{\circ} \mathrm{C}\right)$. The exception is that Gulmarg and Qazigund (being a hilly station) shows less than $0.6^{\circ} \mathrm{C}$ in maximum temperature. The minimum temperature exhibits the lowest increase of $0.3{ }^{\circ} \mathrm{C}$ at Srinagar and highest increase at Gulmarg station of $1.2^{\circ} \mathrm{C}$ (Fig. 2c). Analyses of composite seasonal mean of minimum and maximum temperatures in the valley reveal a higher increase in maximum temperature in winter and spring seasons. Among four stations (Gulmarg, Pahalgam, Kokarnag and Kupwara), Gulmarg indicates an increase of less than $1{ }^{\circ} \mathrm{C}$ while Pahalgam, 
Table 3. Mean temperature increases at each station during 1980-2016.

\begin{tabular}{lrlr}
\hline Stations & Elevation in meters & Topography & $\begin{array}{r}\text { Increase in annual } \\
\text { temperature in }{ }^{\circ} \mathrm{C}\end{array}$ \\
\hline Pahalgam & 2600 & Located on mountain top & 1.13 \\
Gulmarg & 2740 & Located on mountain top & 1.04 \\
Srinagar & 1600 & Located on plane surface in an urbanized area & 0.55 \\
Kupwara & 1670 & Located on plane surface bounded on three sides by mountains & 0.92 \\
Kokarnag & 2000 & Located on plane surface & 0.99 \\
Qazigund & 1650 & Located on plane surface & 0.78 \\
\hline
\end{tabular}

Kokarnag and Kupwara show increases of 0.9, 0.9 and less than $0.9^{\circ} \mathrm{C}$ respectively (Table 1 and Fig. $2 \mathrm{~d}$ ). On the contrary, Qazigund and Srinagar showed a slight increase of less than 0.4 and $0.5^{\circ} \mathrm{C}$ respectively. The mean spring temperature shows a higher rise compared to other seasons temperatures for all stations. Gulmarg shows an increase of less than $1.4^{\circ} \mathrm{C}$. Pahalgam, Kupwara and Kokarnag showed increases of $1.3^{\circ} \mathrm{C}$ at $S=0.01$. Qazigund and Srinagar revealed 0.6 and $1{ }^{\circ} \mathrm{C}$ increase respectively as shown in the Table 1 and Fig. 2e. In summer, the temperature rise for Pahalgam is about less than $0.6^{\circ} \mathrm{C}$ and for Gulmarg and Qazigund, it is about 0.4 and $0.2^{\circ} \mathrm{C}$ respectively (Table 1 ). Kupwara, Kokarnag and Srinagar reveal an increase of less than 0.3, 0.4 and $0.1^{\circ} \mathrm{C}$ respectively (Fig. 2f). In autumn, Gulmarg shows an increase of $0.9^{\circ} \mathrm{C}$ and Pahalgam exhibits less than $0.6^{\circ} \mathrm{C}$. On the contrary Qazigund shows less than $0.4^{\circ} \mathrm{C}$ increase while Srinagar shows no significant increase in observed temperatures (Fig. 2g and Table 1).

\subsection{Trend in annual and seasonal precipitation}

The annual precipitation pattern of the valley is comparable to that of temperature, with a higher decrease observed at the upper elevation stations of Gulmarg and Pahalgam (Fig. 3a and Table 2). Similar to temperature, Table 2 provides in detail the test results of Mann-Kendall, linear regression and Student's $t$. While Kokarnag and Kupwara show significant decrease, the lower elevated stations, Qazigund and Srinagar, exhibit insignificant decreases (Fig. 3a). The decrease in winter precipitation is maximum at Gulmarg and Kokarnag followed by Kupwara and Pahalgam and it is an insignificant decrease for Srinagar and Qazigund (Table 2 and Fig. 3b). The spring season precipitation exhibits a decreasing trend for all six stations, with the lowest decrease of $42 \mathrm{~mm}$ precipitation at Kupwara (Table 2).

During summer months, precipitation also shows a decreasing trend for all stations except Qazigund that it is statistically insignificant (Fig. 3d, and Table 2). For Qazigund there is no apparent trend in summer precipitation. The autumn precipitation also shows an insignificant decreasing trend for the stations (Fig. 3e and Table 2). Cumulative testing was used to determine the "change point" of the trend in the annual and seasonal variations in temperature and pre- cipitation. Results reveal that the year 1995 is the year of abrupt increase (change point) in the temperature of the valley (Fig. 4a) and the same year is identified as the year of abrupt decrease for precipitation (Fig. 4b).

\subsection{Influence of North Atlantic Oscillation (NAO) on the winter precipitation over the Kashmir valley}

The present study also investigates the teleconnection between the activity of the NAO and the variations in temperature and precipitation over the Kashmir valley, particularly during the winter season (December-March). It is found that there is a significant negative/positive correlation $(-0.54 / 0.68)$ between NAO (NAO index) and precipitation/temperature (Fig. 4c). This suggests that winter precipitation and temperature over the Kashmir valley has a close association with the winter NAO. Higher precipitation over Kashmir is associated with a positive phase of NAO. Further the "change point" year, 1995, in the trend of temperature and precipitation coincides with that of the NAO index. To test whether the trends in temperatures and precipitation over the Kashmir valley are forced by the NAO, regression analysis was performed on winter temperature and precipitation (Fig. 4e and f) and the results indicate that there is a significant connection between NAO and precipitation over Kashmir.

The observed annual and seasonal variation in temperature at all stations except Qazigund is strongly correlated with WRF downscaled simulations. Overall, the simulations show correlation of $0.66,0.67,0.72,0.62,0.79$ and 0.47 for Srinagar, Gulmarg, Kokarnag, Kupwara, Pahalgam and Qazigund respectively. The annual mean simulated temperature shows very good correlation (0.85) with observations. Figure 5 shows annual and seasonal correlations between trends of observed and simulated temperatures (location of Kokarnag is considered for WRF data). However, RMSE analysis indicates that model simulations slightly underestimate the observations by an average value of $0.43^{\circ} \mathrm{C}$. Similar to Fig. 5, Fig. 6 shows the comparison between WRF model simulated and observed precipitation. Even though the trend is similar, the WRF model severely underestimates the rainfall amount. A detailed study on this topic will be presented in a separate paper. 

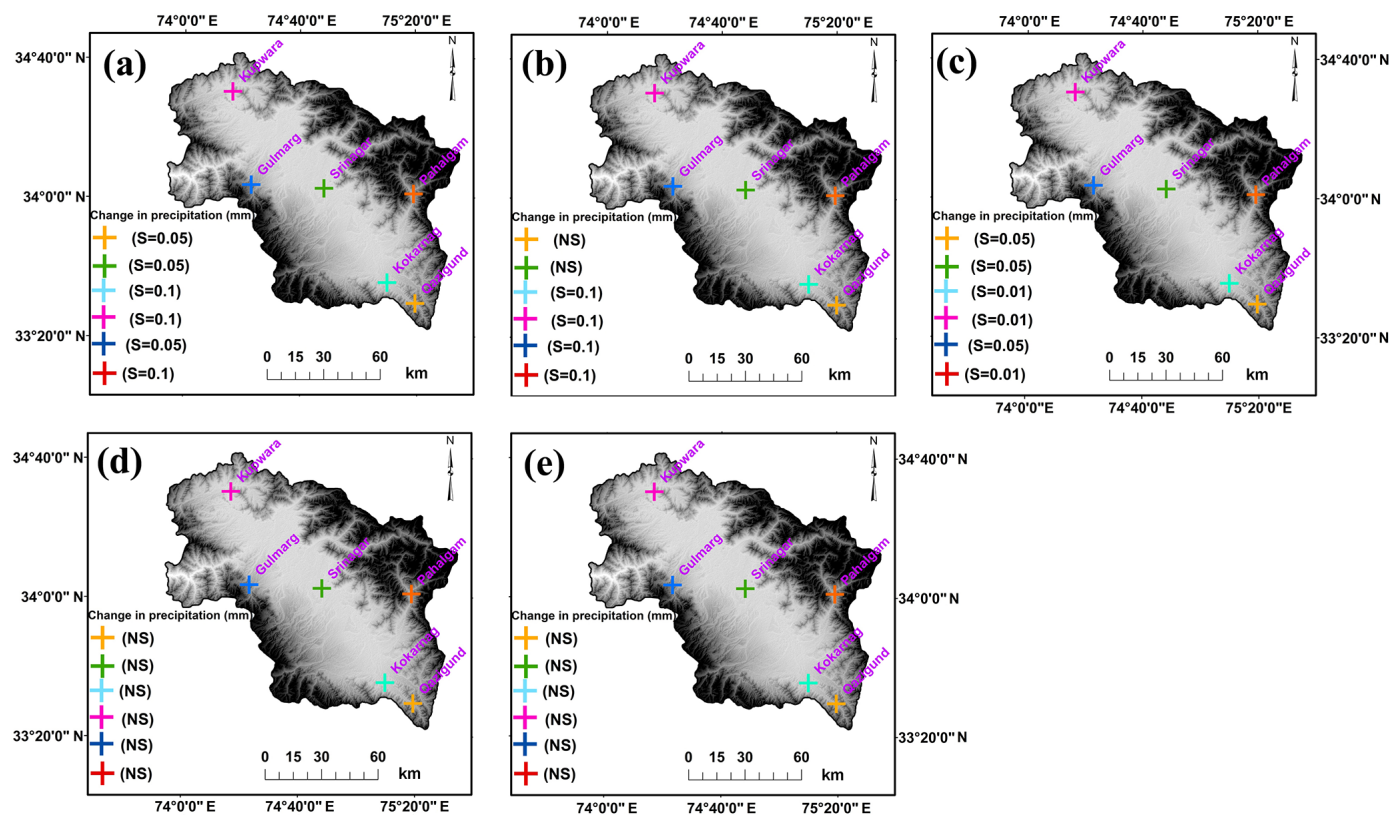

Figure 3. Same as Fig. 2 but for precipitation (mm) and only for means of (a) annual, (b) winter, (c) spring, (d) summer and (e) autumn.
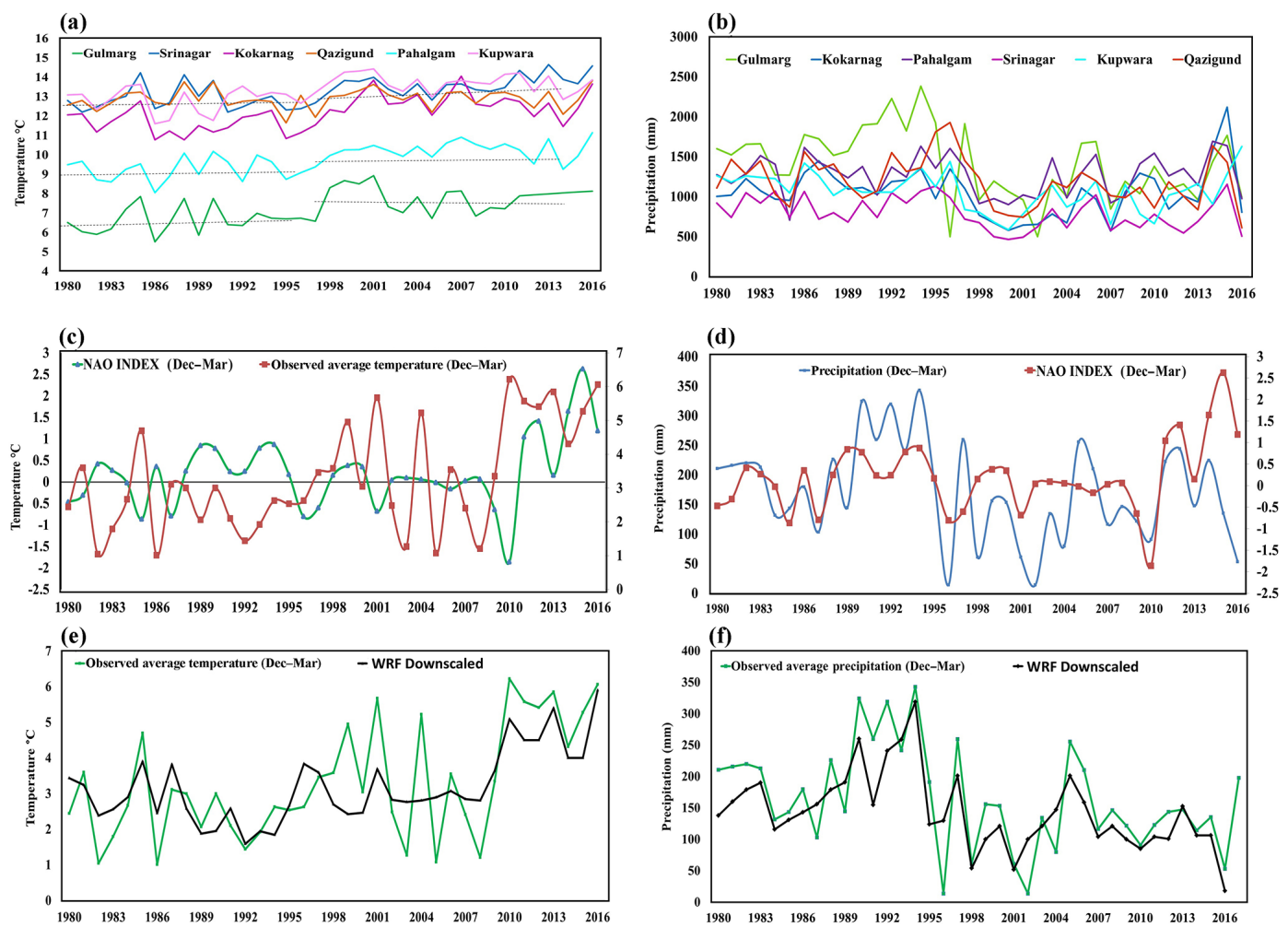

Figure 4. (a) Cumulative testing for defining change point of temperature (averaged for all six stations of the Kashmir valley), (b) same as (a) but for precipitation, (c) comparison of trends of Kashmir temperature with North Atlantic Ocean (NAO) index, (d) same as (c) but for precipitation, (e) regression analysis of winter temperature and (f) regression analysis of winter precipitation. 

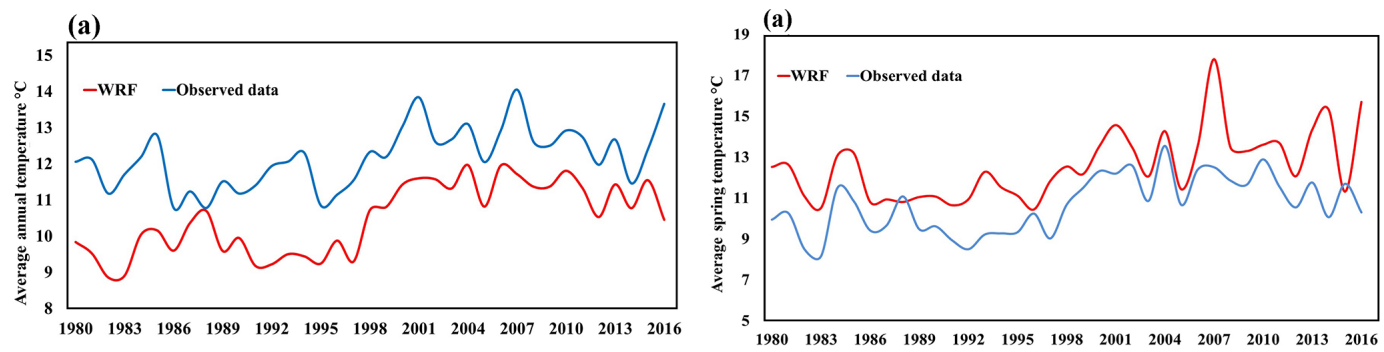

(c)
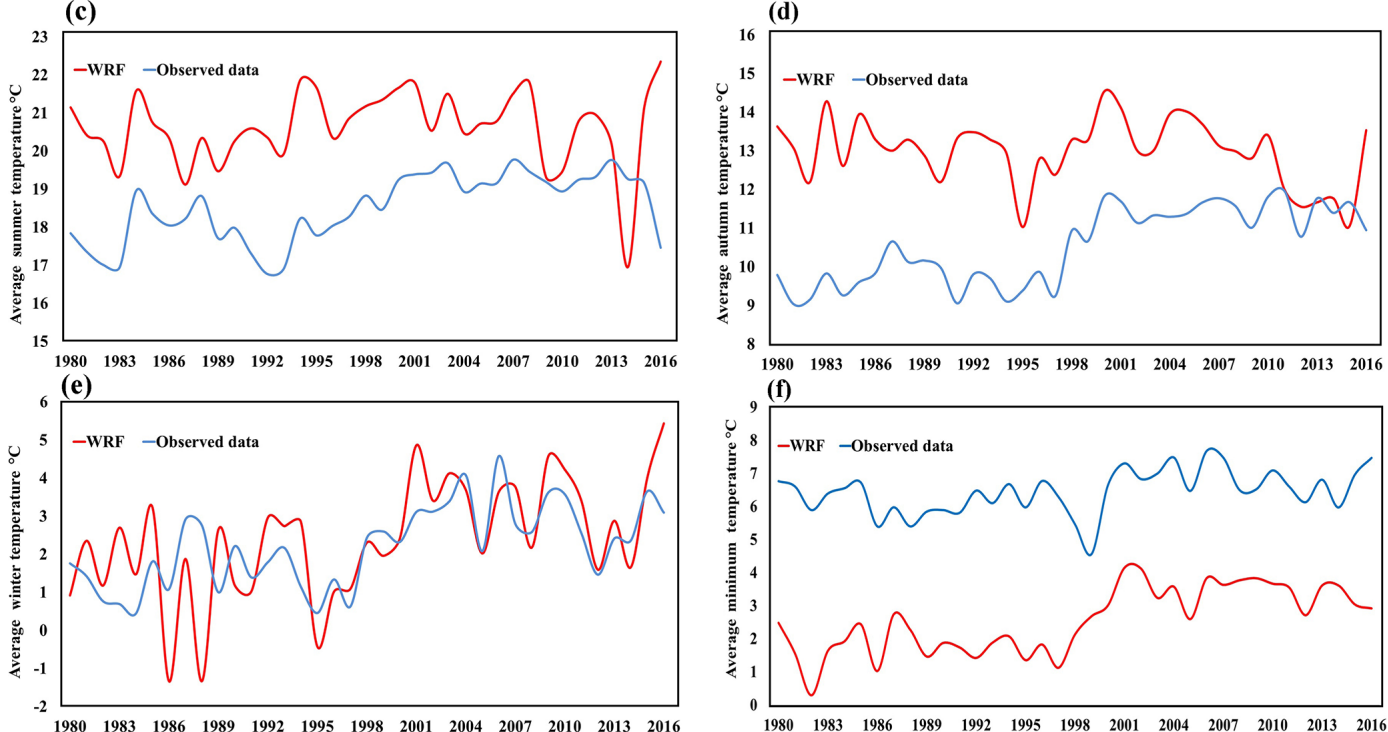
(f)
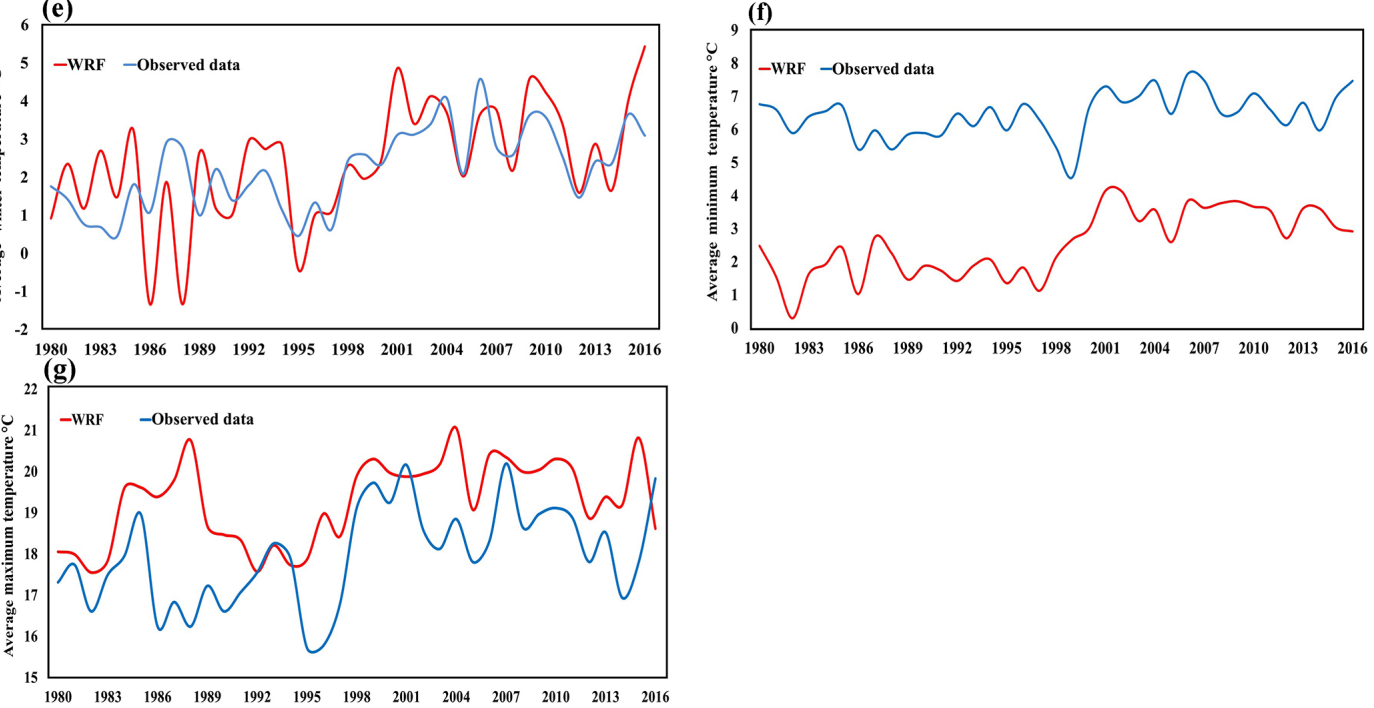

Figure 5. (a) Comparision between observed and WRF model (location of Kokarnag is considered) simulated annually averaged temperature (averaged for all the stations) variations for the years 1980-2016, (b) same as (a) but for spring season, (c) for summer, (d) for autumn, (e) winter, (f) for minimum temperature and (g) maximum temperature.

\subsection{Discussion}

The Himalayan mountain system is quite sensitive to global climate change as the hydrology of the region is mainly dominated by snow and glaciers, making it one of the ideal sites for early detection of global warming (Solomon et al., 2007; Kohler and Maselli, 2009). Various reports claim that in the Himalayas significant warming occurred in the last century (Fowler and Archer, 2006; Bhutiyani et al., 2007). Shrestha et al. (1999) analyzed surface temperature at 49 stations located across the Nepalese Himalayas and the results indicate warming trends in the range of 0.06 to $0.12{ }^{\circ} \mathrm{C}$ per year. The observations of the present study are in agreement with the studies carried out by Shrestha et al. (1999), Archer and Fowler (2004) and Bhutiyani et al. (2007). In the present study, it is observed that rises in temperature are larger at the higher-altitude stations of Pahalgam $\left(1.13^{\circ} \mathrm{C}\right)$ and Gulmarg $\left(1.04^{\circ} \mathrm{C}\right)$ and they are about $0.9,0.99,0.04$ and $0.10^{\circ} \mathrm{C}$ for the other stations, Kokarnag, Kupwara, Srinagar and Qazigund respectively during 1980-2016. Liu et al. (2009) and Liu and Chen (2000) also report higher warming trends at higher altitudes in the Himalayan regions. In the future, the impacts of climate change will be intense at higher elevations and in regions with complex topography, which is consistent with the model results of Wiltshire (2013).

A noteworthy observation in the present study is that statistically significant steep increase in the temperature (change point) occurred in the year 1995 and it has been continuing thereafter. The mega El Niño in 1998 is consid- 

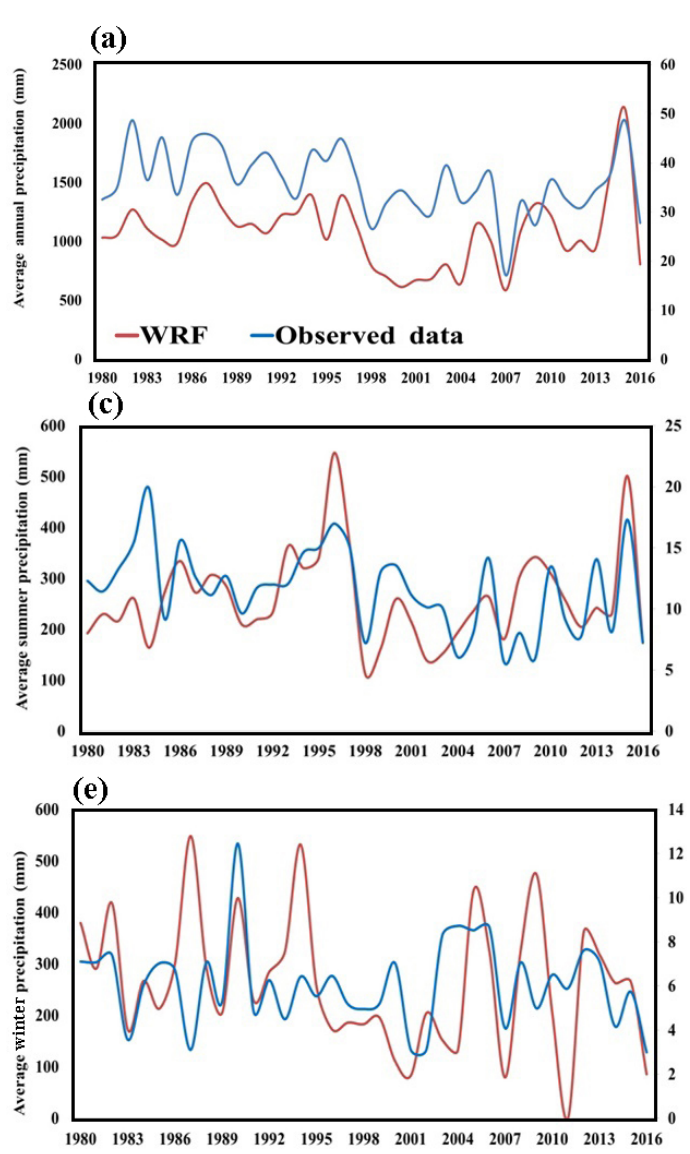

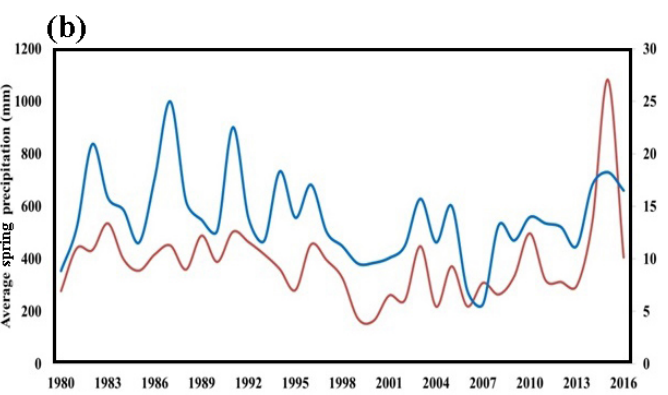

(d)

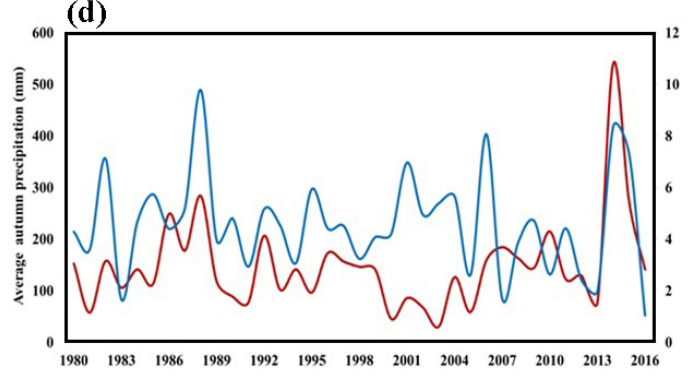

Figure 6. Same as Fig. 5 but for precipitation. Here the minimum and maximum precipitation values are not considered because they cannot be defined properly within a day.

ered one of the strongest El Niño events in history and led to a worldwide increase in temperature. Contrastingly, the El Niño in 1992 led to a decrease in temperature throughout the Northern Hemisphere, which is ascribed to the Mt Pinatabu volcanic eruption (Swanson et al., 2009; IPCC, 2013). Also, this event prevented direct sunlight reaching some areas of the surface of the Earth for about 2 months (Barnes et al., 2016).

Studies of trends in seasonal-mean temperature in many regions across the Himalayas indicate higher warming trends in winter and spring months (Shrestha et al., 1999; Archer and Fowler, 2004; Bhutiyani et al., 2009). The seasonal difference found in the present study is consistent with other studies carried out for the Himalayas (Archer and Fowler, 2004; Sheikh et al., 2009; Roe et al., 2003); Lancang Valley, China (Yunling and Yiping, 2005); Tibet (Liu and Chen, 2000) and the Swiss Alps (Beniston, 2010), where almost all stations recorded a higher increase in the winter and spring temperatures compared to autumn and summer temperatures. Recent studies found that a reduction in the depth of snow cover and shrinking glaciers may also be one of the contributing factors for the observed higher warming, as the re- duction in the percentage of snow and glacier can alter the surface albedo over a region, which in turn can increase the surface air temperatures (Kulkarni et al., 2002; Groisman et al., 1994). Romshoo et al. (2015) and Murtaza and Romshoo (2016) have also reported that a reduction in snow and glacier cover in the Kashmir regions of the Himalayas during recent decades could be one of the reasons for the occurrence of higher warming, particularly on the higher elevated stations of Gulmarg and Pahalgam.

In the Himalayan mountain system, contrasting trends have been noted in precipitation over recent decades (IPCC, 2001). Borgaonkar and Pant (2001), Shrestha (2000) and Archer and Fowler (2004) observed increasing precipitation patterns over the Himalayas while Mooley and Parthasarthy (1984), Kumar and Jain (2010) and Dimri and Dash (2012) reported large-scale decadal variation with increasing and decreasing precipitation periods. The results of the present study indicate that the decrease in annual precipitation is slightly insignificant at all six stations except in the spring season. The increasing trend in temperature can trigger largescale energy exchanges that become more intricate as complex topography alters the precipitation type and intensity in 


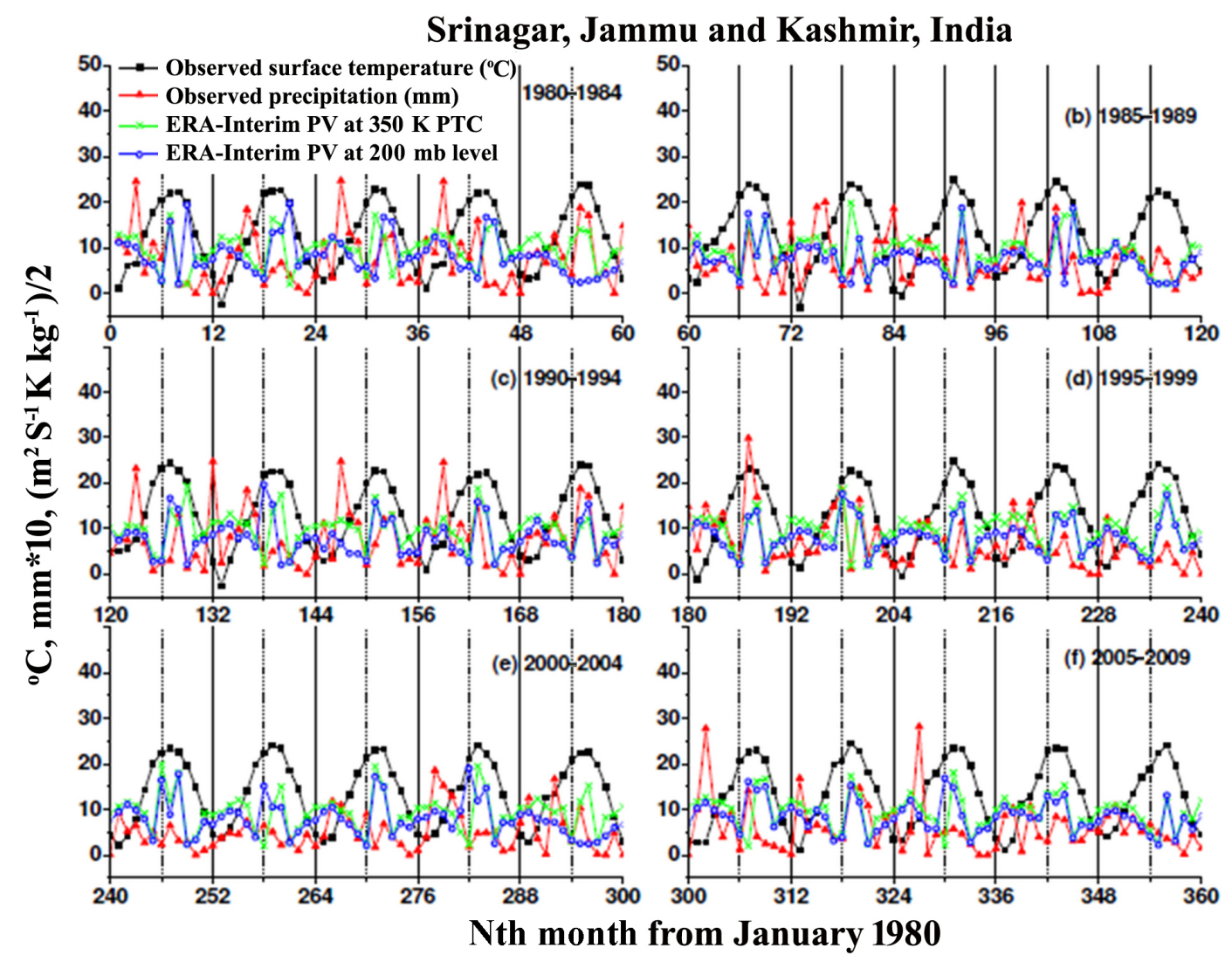

Figure 7. Observed monthly averaged surface temperature and precipitation as well as ERA-interim potential vorticities at the $350 \mathrm{~K}$ potential temperature and $200 \mathrm{hPa}$ pressure surfaces for the Srinagar station during the years 1980-2016.

many ways (Kulkarni et al., 2002; Groisman et al., 1994). Climate model simulations (Zarenistana et al., 2014; Rashid et al., 2015) and empirical evidence (Vose et al., 2005; Romshoo et al., 2015) also confirm that increasing temperature results in increased water vapor, leading to more intense precipitation events even when the total annual precipitation reduces slightly. The increase in temperature therefore enhances the risks of both floods and droughts. For example, the disaster flood event of September 2014 occurred in the Kashmir valley due to high-frequency and high intense precipitation.

The NAO is one of the strongest northern atmospheric weather phenomena occurring due to the difference of atmospheric pressure at sea level between the Iceland low and Azores high. It controls the strength and direction of westerly winds across the Northern Hemisphere. Surface temperatures have increased in the Northern Hemisphere in the past few decades (Mann et al., 1999; Jones et al., 2001; Hijioka et al., 2014), and the rate of warming has been especially high $\left(\sim 0.15^{\circ} \mathrm{C}\right.$ decade $\left.^{-1}\right)$ in the past 40 years (Folland et al., 2001; Hansen et al., 2001; Peters et al., 2013; Knutti et al., 2016). The NAO causes substantial fluctuations in the climate of the Himalayas (Hurrell and van Loon, 1997; Syed et al., 2006; Archer and Fowler, 2004). Several workers found a strong connection between the NAO and temperature and precipitation in the north-western Himalayas (Archer and Fowler, 2004; Bhutiyani et al., 2007; Bookhagen, 2010; Sharif et al., 2013; Iqbal and Kashif, 2013). A substantial fraction of the most recent warming is linked to the behavior of the NAO (Hurrell and van Loon, 1997; Thompson et al., 2003; Madhura et al., 2015). The climate of the Kashmir Himalayas is influenced by western disturbances in winter and spring seasons. Figure $4 \mathrm{c}$ and $\mathrm{d}$ show correlation between wintertime NAO and temperature and precipitation over the Kashmir region. While temperature shows a negative correlation of -0.54 , precipitation shows a positive correlation of 0.68 . From linear regression analyses, it is found that considerable variation in winter precipitation and temperature over Kashmir is forced by winter NAO. The weakening link of NAO after 1995 has a close association with decreased winter precipitation and increased winter temperature in the valley. Similarly, Bhutiyani et al. (2009) and Dimri and Dash (2012) also found a statistically significant decreasing trend in precipitation which they related to weakening of NAO index. However, to establish a detailed mechanism, incorporating these variations requires thorough investigation.

The WRF model simulations compare well with observations (significantly strong correlation of 0.85 ) and the corre- 


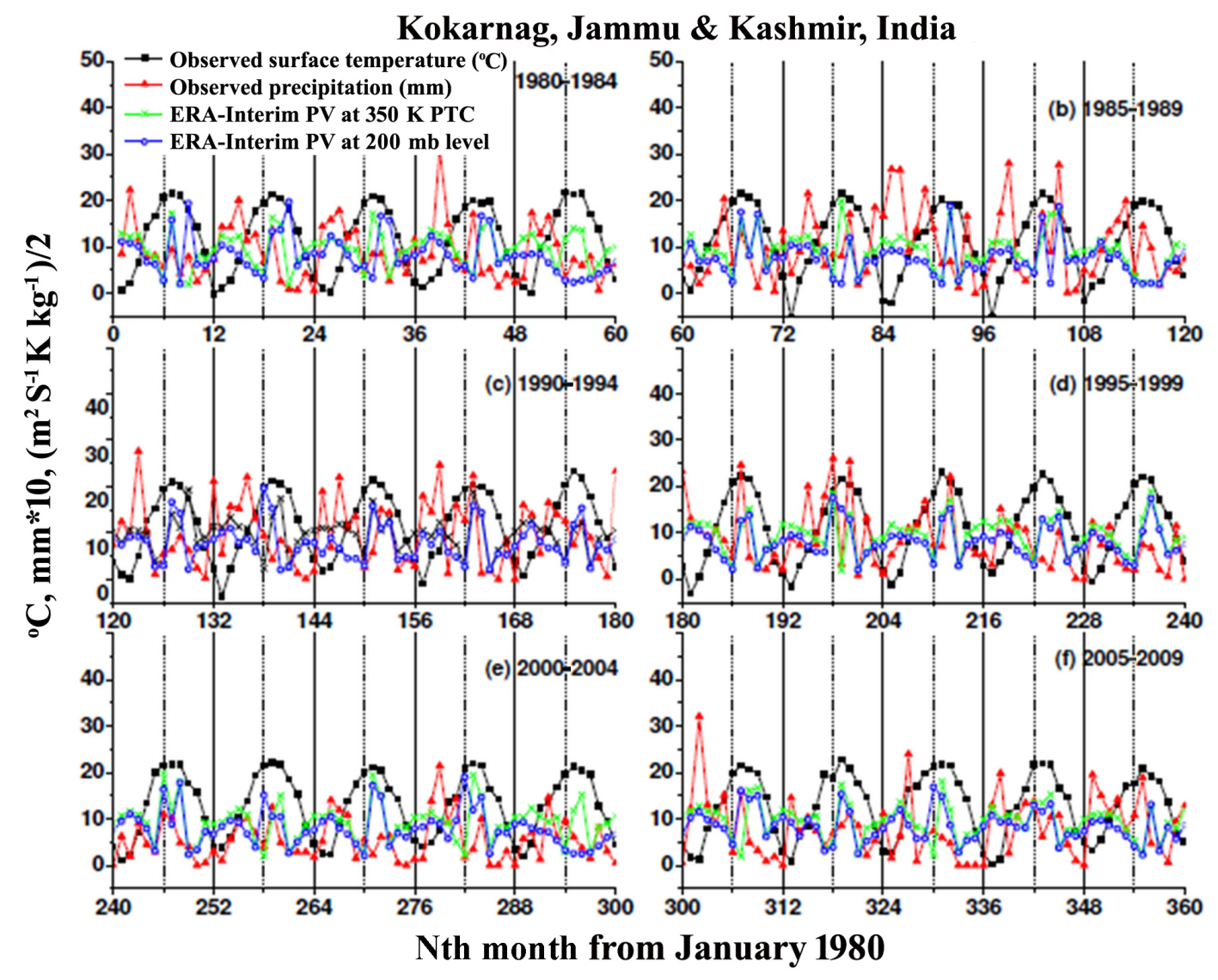

Figure 8. Same as Fig. 6 but for Kokarnag.

lation is more for the elevated stations than the valley stations of Srinagar and Kupwara. However, it is expected that a good correlation can result if more precise terrain information is incorporated in the WRF model simulations. Earlier studies (e.g. Kain and Fritsch, 1990, 1993; Kain, 2004) also found good correlation between observed and WRF simulated rainfall events. In conjunction with large-scale features such as $\mathrm{NAO}$ and ENSO, it can result in large-scale variability in the climate of this region (Ogura and Yoshizaki, 1988). Furthermore, incorporation of mesoscale teleconnections and their associations in the WRF model can further help in understanding large-scale weather forecasting over this region.

\subsection{Physical mechanisms of climate and weather of Jammu and Kashmir}

Large-scale spatial and temporal variations in the meridional winds could be due to the passage of planetary-scale Rossby waves in the atmospheric winds. When RWs break in the upper troposphere, it could lead to vertical transport of atmospheric air between the upper troposphere and lower stratosphere and an irreversible horizontal transport of air mass between the subtropics and extratropics (McIntyre and Palmer, 1983). Rossby waves have the characteristic of remaining co- herent over many days and propagate long distances of the order of synoptic to planetary scales, leading to the teleconnection of remote atmospheres of global extent. The study by Chang and Yu (1999) indicates that during northern winter months of December-January-February, Rossby wave packets can be most coherent over a large distance of from the northern Africa to the Pacific through southern Asia. There are reports of extreme weather events connected to Rossby waves of synoptic to planetary scales in the upper troposphere (e.g. Screen and Simmonds, 2014). In northern India, there is an increasing trend in heavy rainfall events, particularly over the Himachal Pradesh, Uttrakhand, and Jammu and Kashmir (Sinha Ray and Srivastava, 2000; Nibanupudi et al., 2015). Long Rossby waves can lead to the generation of alternating convergence and divergence in the upper troposphere that in turn can affect surface weather parameters like precipitation through the generation of instabilities in the atmospheric air associated with convergence and divergence (Niranjan Kumar et al., 2016).

Using observations and MERRA (Modern-Era Retrospective Analysis for Research and Applications reanalysis; https: //gmao.gsfc.nasa.gov/research/merra/, last access: 19 December 2018) data, Rienecker et al. (2011) showed strong correlation between $6-10$ days periodic oscillations associ- 


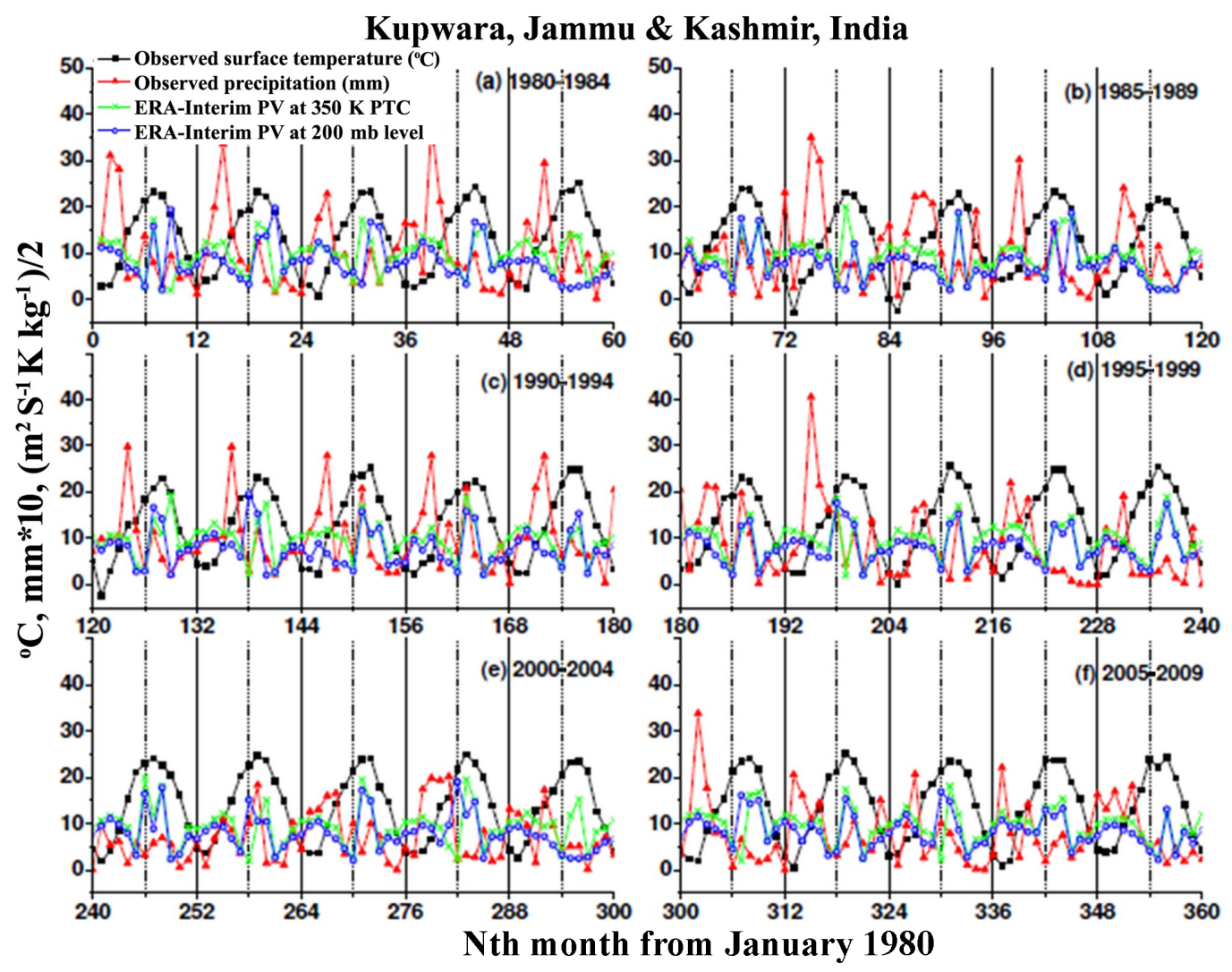

Figure 9. Same as Fig. 7 but for Kupwara.

ated with Rossby waves in the upper tropospheric winds and surface weather parameters like atmospheric pressure, winds, temperature, relative humidity and rainfall during a severe weather event observed at the Indian extratropical station, Nainital $\left(29.45^{\circ}, 79.5^{\circ}\right)$, in November-December 2011. They also note that when the upper troposphere shows divergence, the lower troposphere shows convergence and as a result more moisture gets accumulated there, leading to enhancement of relative humidity and hence precipitation. It was asserted that Rossby waves in the upper troposphere can lead to surface weather-related events through the action of convergence or divergence in the atmospheric air. It is to be noted that a passing Rossby wave can cause fluctuations in divergence and convergence in the atmosphere at periodicities (typically $6-10$ or 12-20 days) corresponding to the Rossby waves at a particular site.

It was reported that Rossby waves account for more than $30 \%$ of monthly mean precipitation and more than $60 \%$ of surface temperature over many extratropical regions and influence short-term extreme weather phenomena (Schubert et al., 2011). Planetary waves affecting weather events severely for long durations of the order of months have been reported by many researchers (Petoukhov et al., 2013; Screen and Simmonds, 2014; Coumou et al., 2014). Screen and Simmonds (2014) found that in the midlatitudes, there was a strong association between enhanced Rossby wave activity, surface temperature and extreme precipitation events in 1979-2012. Since slowly propagating Rossby waves can influence weather at a particular site for long periods lasting more than few weeks, it is can be seen the imprint of climatic variations in Rossby waves in weather events from monthly mean atmospheric parameters.

To understand the present observation of different precipitation characteristics over different stations, it is compared between monthly variation in PV in the upper troposphere and precipitation. Potential vorticity at $350 \mathrm{~K}$ surface is identified for investigating Rossby waves as their breakage (can be identified through reversal of gradient in PV) at this level can lead to an exchange of air at the boundary between the tropics and extratropics (Homeyer and Bowman, 2013). Similarly PV at $200 \mathrm{hPa}$ pressure surface is more appropriate for identifying Rossby wave breaking in the subtropical regions (Garfinkel and Waugh, 2014).

Since the Srinagar city is located on comparatively flat land compared to the other six stations of the Kashmir valley, precipitation associated with western disturbances here is under the direct influence of planetary-scale Rossby waves. Accordingly, correlation between PV at the $350 \mathrm{~K}$ (located near the core of the subtropical jet; Homeyer and Bowman, 2013) and $200 \mathrm{hPa}$ pressure surface and precipitation is found 


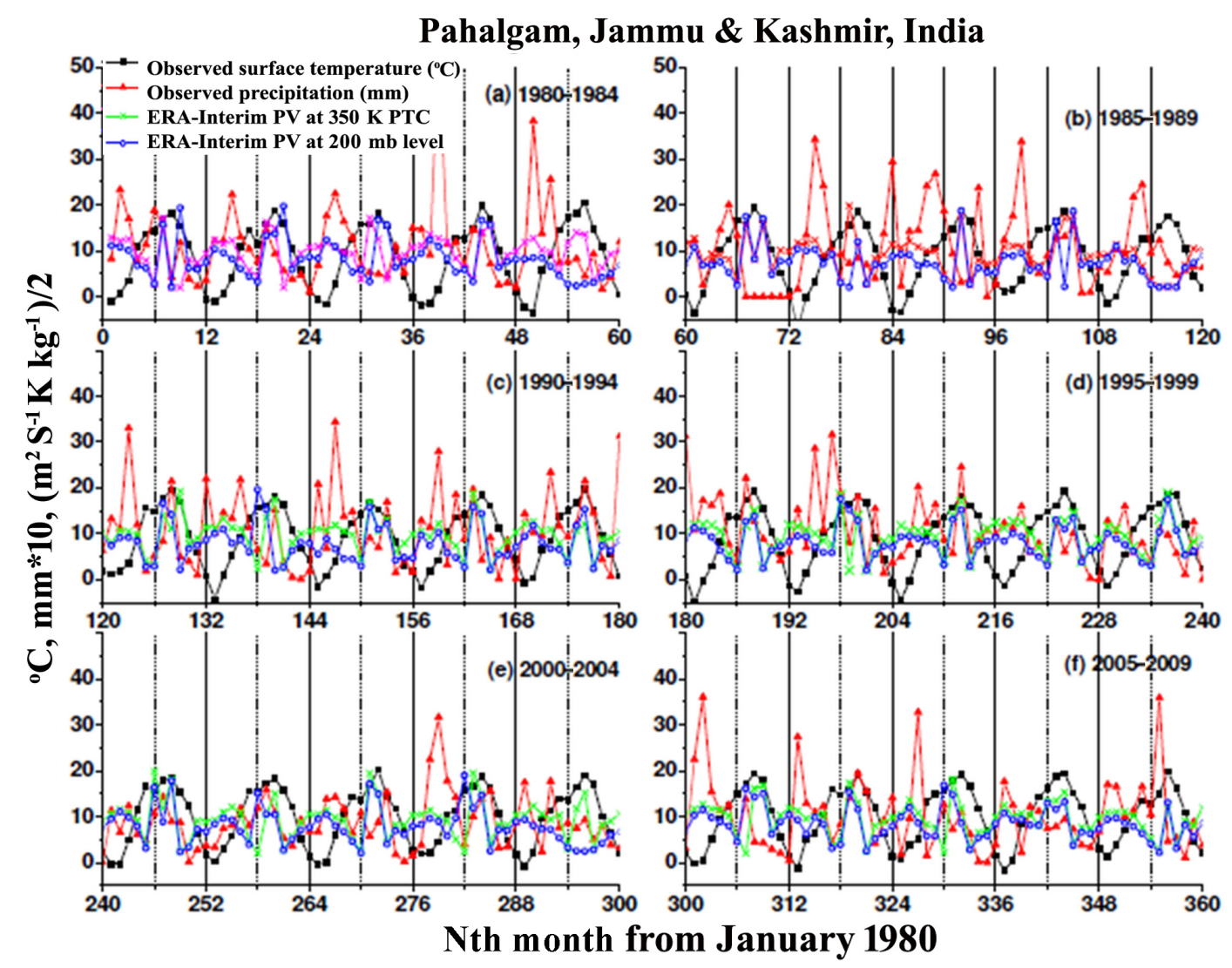

Figure 10. Same as Fig. 8 but for Pahalgam.

to be significantly larger over Srinagar than other stations. Orographic effects at other stations can have significant influence on planetary Rossby waves. Therefore, PV (ERAInterim data, Dee et al., 2011) in the upper troposphere varies in accordance with precipitation, which is clearly depicted in Fig. 7, during the entire years of 1984, 1987, 1988, 1990, 1993, 1994, 1995, 1996, 1999, 2006 and 2009. Sometimes, it is observed that the time variation of precipitation has strong correlation with PV at either $350 \mathrm{~K}$ surface or $200 \mathrm{hPa}$ pressure surface. This would be due to the influence of Rossby waves generated due to baroclinic or and barotropic instabilities. Particularly, the correlation between PV (sometimes either one or both) and precipitation is significantly positive during the Indian summer monsoon months of JuneSeptember for all the years from 1980 to 2009 except 1983, 1985, 1989, 2000-2005 and 2009. At present it is not known why this relation became weak during 1999-2010.

For Kokarnag (Fig. 8), the topography of which is similar to Srinagar but which is located in the vicinity of high mountains, the relation between PV and precipitation particularly during the Indian summer monsoon is almost similar to that of Srinagar during 1983, 1985, 1989, 1991, 1998, 1999 and 2000-2005. The deterioration of the link between PV and rainfall over Kokarnag and Srinagar during 1999-2010 is intriguing and it may be associated with climate change. In the northern Kashmir region of Kupwara (Fig. 9), at mean sea level which is $\sim 1 \mathrm{~km}$ higher than Srinagar, the relation between PV and precipitation is good in the years 1982-1983, 1985-1988, 1990-1994, 1995-1996, 1999 and 2006. Similar to Srinagar and Kokarnag, Kupwara also shows a poor link during 1999-2010. Particularly during the summer monsoon period, the PV-precipitation relation is good in all the years except 1989, 1998, 2000-2005 and 2009. One interesting observation is that in 1983, 1985 and 1991 the correlation between PV and precipitation for Kupwara is better than Srinagar and Kokarnag. Since Kupwara is located nearelevated Greater Himalayan mountain range, Rossby waves associated with topography would have contributed to the good correlation between PV and precipitation here, which is not the case for Srinagar and Kokarnag. In the case of Pahalgam, (Fig. 10), located near the Greater Himalayas, generally the link between PV and precipitation is good in almost all the years in the period 1980-2016 but with a difference that sometimes both the PVs follow precipitation and at other times only one of them does. Particularly during summer monsoon months, similar to Kupwara, the years 1989, 2000-2003, 2005 and 2009 show poor correlation. In general, precipitation near the Greater Himalayas is significantly influenced by Rossby waves associated with topography. 


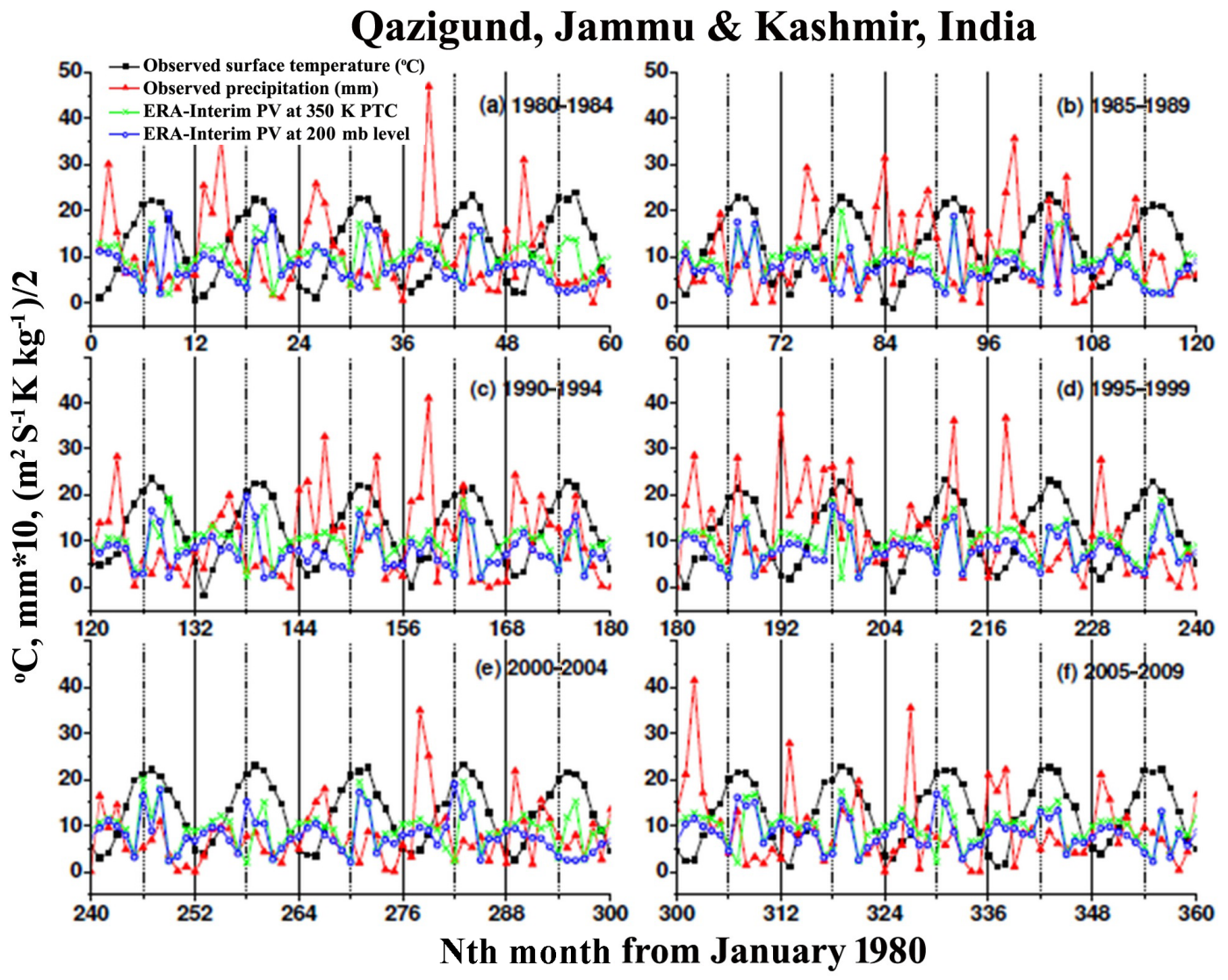

Figure 11. Same as Fig. 9 but for Qazigund.

For the hilly station of Qazigund (Fig. 11), located in the south Kashmir region (above $\sim 3 \mathrm{~km}$ m.s.l.) near the foothills of Pir Panjal mountain range, the relation between PV and precipitation is better than that of the northern station Kupwara. For example, in 1988, the relation is much better over Qazigund than Kupwara. However, the opposite is true in 1987. Interestingly, in 1985, both Kupwara and Qazigund show similar variation in PV and precipitation. This may be due to the effect of the nature of limited equatorward propagation of Rossby waves from midlatitudes. In 1995, 1997 and 1998, PV and precipitation follow similar time variation at both Kupwara and Qazigund except for January-March during which precipitation over Qazigund but not Kupwara follows PV. Interestingly, in the whole year of 1999, precipitation at both stations follows exceedingly well with PV; however, in 1998, only Qazigund but not Kupwara shows good relation. In 2009, precipitation does not follow PV for both stations. Interestingly in all the months of 2006, PV follows well with precipitation for both Kupwara and Qazigund. However in September, Kupwara but not Qazigund shows good relation. In 2004, only PV at $350 \mathrm{~K}$ surface follows well with precipitation for both the stations. For the summer monsoon period of June-September, these years, namely, 1983, 1985, 1989, 1990, 2000-2003, 2005 and 2007-2009, do not show good correlation, which is almost similar to Srinagar and Kokarnag.

In the case of Gulmarg (Fig. 12), PV and precipitation follow each other well in the years of 1988, 1993, 1994 and 1995. In 1996, during the Indian summer monsoon period of June-September, only PV at $350 \mathrm{~K}$ surface follows precipitation. Overall, during the summer monsoon period, the relationship between PV and precipitation is appreciable for all the years except for 1983, 1989, 1990, 1999 and 2000-2009, which is almost similar to Kupwara and Pahalgam. It may be noted that these stations are located near relatively elevated mountains and hence topographically induced Rossby waves could have contributed to this good relation. The observations suggest that high-altitude mountains affect the precipitation characteristics through topography-generated Rossby waves. The interesting finding here is that irrespective of the different heights of mountains, all the stations show that during 1999-2010 the correlation between upper tropospheric PV and surface precipitation was found to be poor, indicating that some unknown new atmospheric dynamical concepts would have played significant role in disturbing the precipitation characteristics significantly over the western Himalayan region. This issue needs to be addressed in the near future by 


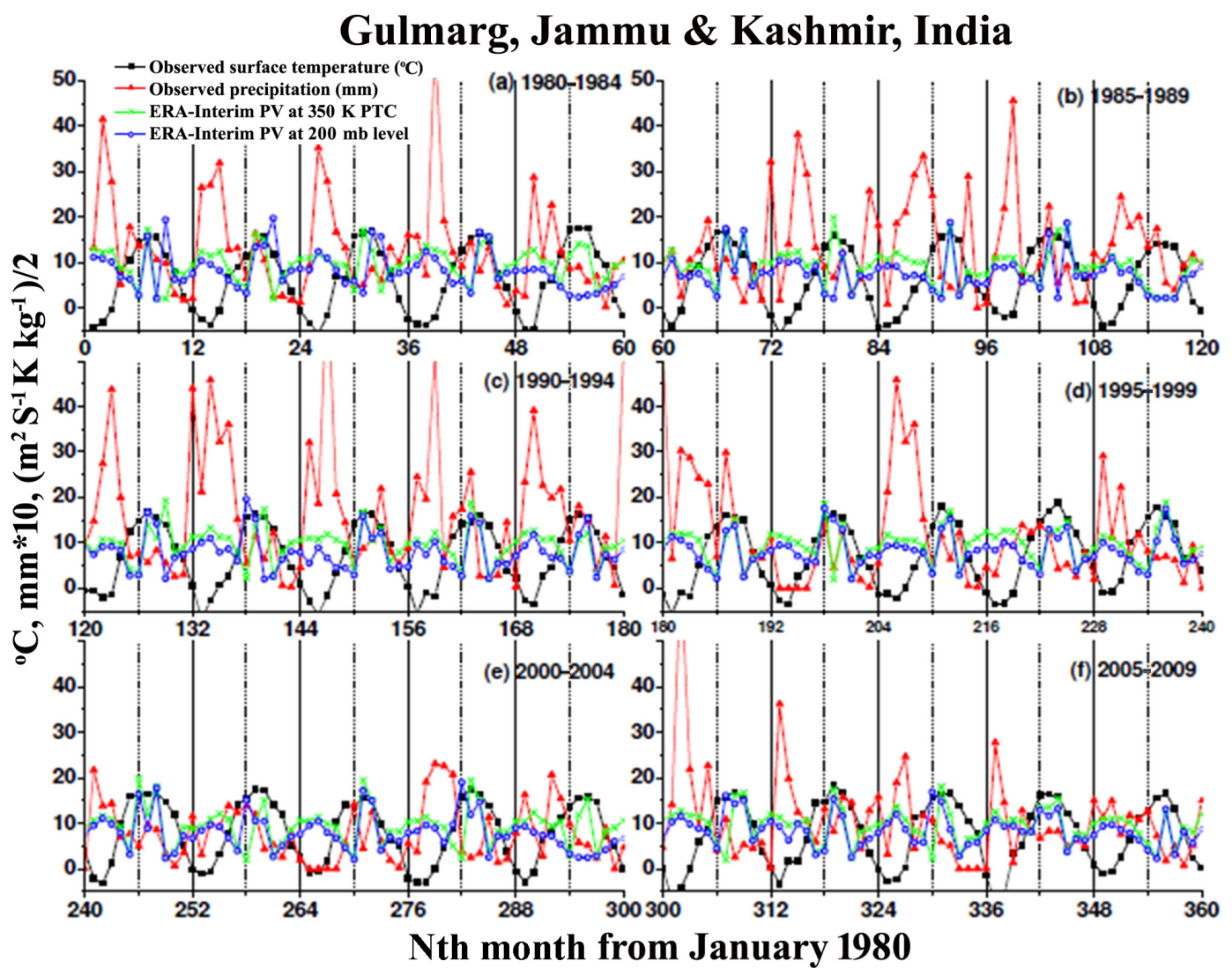

Figure 12. Same as Fig. 10 but for Gulmarg.

invoking suitable theoretical models so that predictability of extreme weather events can be improved in the Himalayas.

During 2011-2016 (Fig. 13), it may be observed that for Gulmarg the link between PV and precipitation holds well in general for all these years except around July 2012, JulyDecember 2013 and 2015. It is interesting to note here that during the historical flood event of September 2014, the $\mathrm{PV}$ and precipitation follow each other but in the preceding and following years of 2013 and 2015 their linkage is poor, as noted earlier. Similarly, all the other stations (Srinagar, Pahalgam, Kokarnag, Kupwara and Qazigund) also show that the link between PV and precipitation is good around September 2014. This would indicate clearly that the extreme weather event that occurred during September 2014 is due to intense large-scale Rossby wave activity rather than any localized adverse atmospheric thermodynamical conditions such as local convection. In Srinagar, most of the time PV and precipitation follow each other very well as observed during January 2011-June 2012, JanuaryJuly 2013, January-July 2014, and all of 2015 and 2016. In Qazigund, this relation is good only during January-July and September-October 2014 and during all of 2015 and 2016 (similar to Srinagar). For Kupwara, PV follows precipitation well during all of 2011, January-July 2012, JanuaryMay 2013, January-November 2014, and all of 2015 and
2016. In the case of Kokarnag, a good relation is observed during March-August 2012, January-June 2013 and 2014, around September 2014. In contrast, the relationship is very poor in the entire years of 2015 and 2016. Pahalgam interestingly shows good correlation between PV and precipitation during the whole years of 2011 and 2012. In 2013, 2014, 2015 and 2016, it is good only during January-June in addition to being exceptionally good in September 2014.

Finally, it may be observed that the ERA-interim reanalysis data of meridional wind velocity (12:00 UT) at $\sim 3 \mathrm{~km}$ altitude above the mean seal level show alternating positive (southerly) and negative values, resembling the atmospheric Rossby waves in the subtropical region during 1-6 September 2014 (Fig. 14). The meridional winds associated with Rossby waves could be easily identified to have their extensions in both the Arabian Sea and Bay of Bengal, indicating that water vapor from both regions was transported towards the Jammu and Kashmir region of India as the converging point of Rossby waves was located near this region. It may be easily noticed that the waves got strengthened on 4 and weakened on 5 September and ultimately dissipated on 6 September. This dissipation of Rossby waves led to dumping of the transported water vapor over this region and thus caused the historical-record heavy-flooding during this period. This is one clear example of how synoptic-scale Rossby waves can 


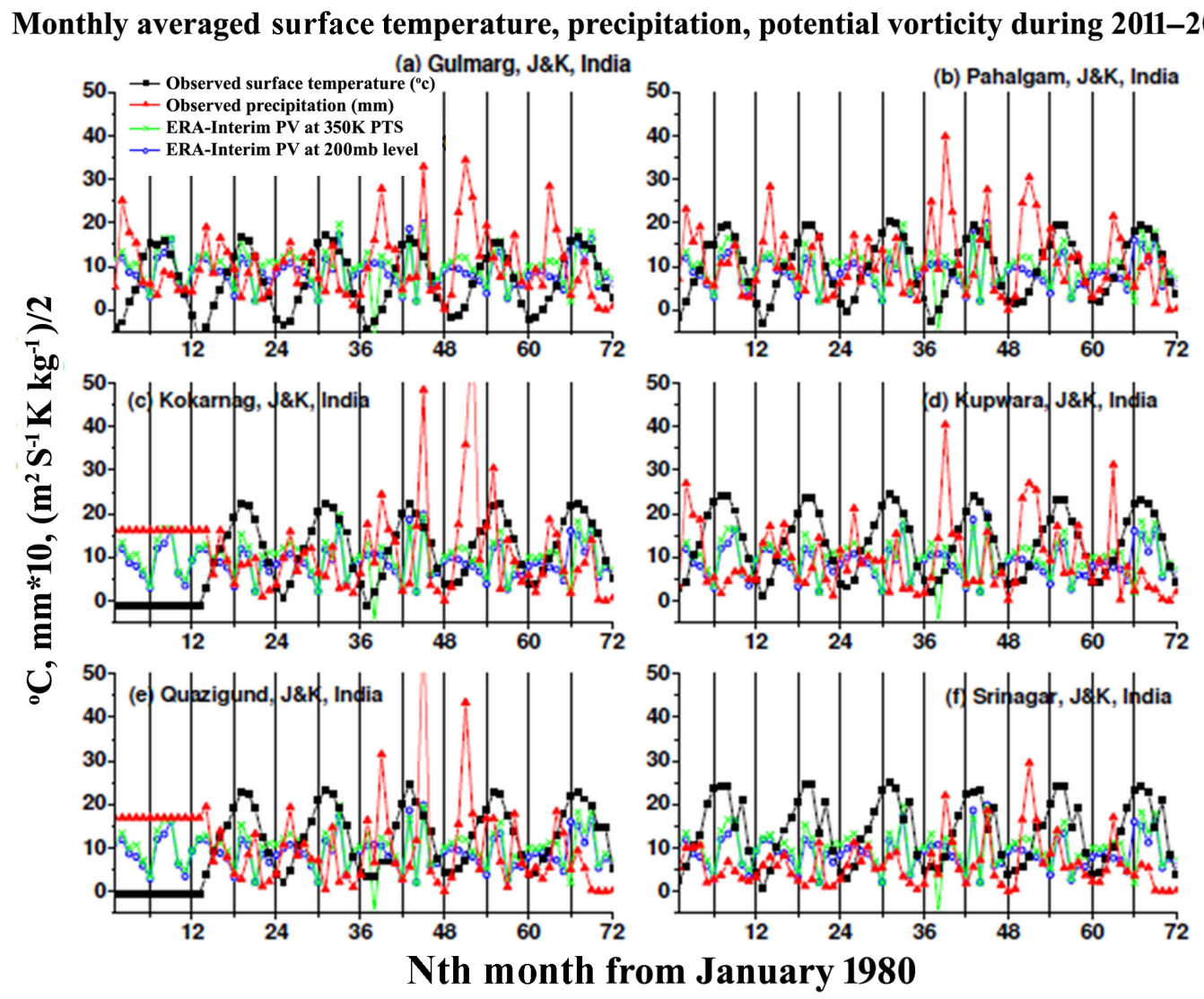

Figure 13. Same as Fig. 11 but for all the stations and during the years 2011-2016.

reorganize water vapor over large scales and lead to extreme rainfall events. It is well known that the subtropical westerly jet is one of many important sources of Rossby waves in the midlatitudes to tropical latitudes. If the subtropical jet drifts climatically northward then the surface weather events associated with them also will drift similarly, leading to unusual weather changes climatically.

Published reports by Barnes and Polvani (2013) and Lu et al. (2014) indicate that long-term variations in Rossby wave breaking activities and stratospheric dynamics have close association with global climate change. A meridional shift of the center of subtropical jets, arising due to enhanced polar vortex and upper-tropospheric baroclinicity, is possible due to the consequences of global warming, has been successfully linked to climatic changes in Rossby wave breaking events caused by baroclinic instabilities (Wittman et al., 2007; Kunz et al., 2009; Rivière, 2011; Wilcox et al., 2012). The long-term increase in the tropospheric warming arising due to baroclinic forcing of Rossby waves is more prominent in the midlatitudes than in the tropical regions (Allen et al., 2012; Tandon et al., 2013). This midlatitude warming plays a critical role in driving poleward shifts of the subtropical jet responding to climate change (Ceppi et al., 2014). It should be remembered that the combined effect of tropo- spheric baroclinic forcing (warming) and a stratospheric polar vortex can gradually move the subtropical jet from about 27 to $54^{\circ}$ (Garfinkel and Waugh, 2014). Using global circulation models (GCMs), linear wave theory predicts that in response to increased greenhouse gas (GHG) forcing, midlatitude eddy-driven jets, arising due to strong coupling between synoptic-scale eddy activity and jet streams in both the hemispheres, will be shifted poleward (Fourth report of Intergovernmental Panel on Climate Change (IV-IPCC), Meehl et al., 2007). However, midlatitude Rossby waves and the associated wave dissipation in the subtropical region are predicted to move climatologically towards the equator due to the spherical geometry of the Earth (Hoskins et al., 1977; Edmon et al., 1980). This propagation of the location of wave breaking towards the equator will have a long-term (climatic) impact on the relation between variations in upper tropospheric PV associated with Rossby waves and surface precipitation in the subtropical latitude regions. This may be one of the reasons that during 1999-2010, the relation between $\mathrm{PV}$ and precipitation became poor, as observed in the present study.

Regarding surface temperature, except for its linear longterm trend, there is no clear evidence of a strong link between variations in the upper tropospheric potential vorticities and 


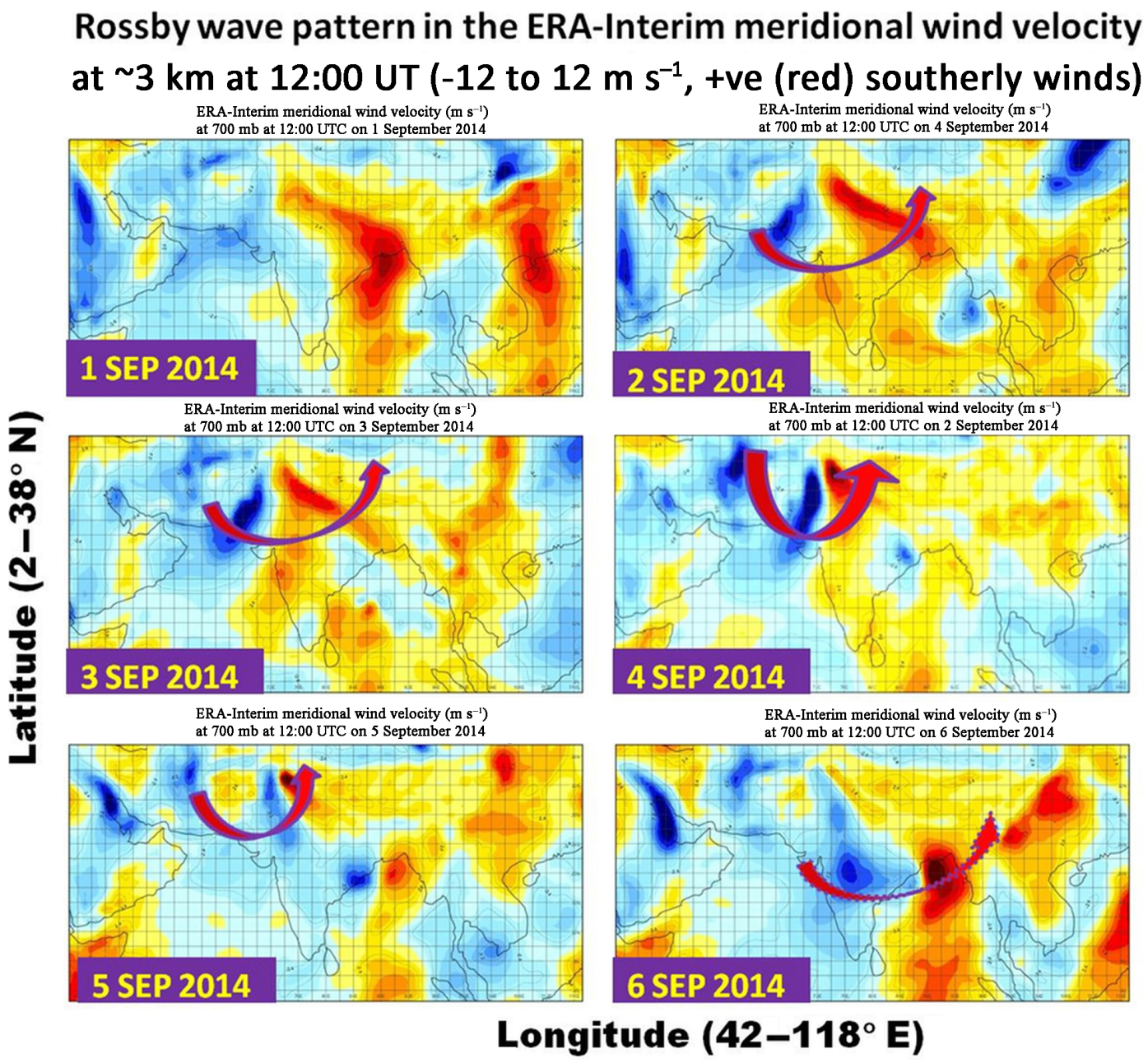

Figure 14. Synoptic-scale ERA-interim meridional wind velocity covering the Jammu and Kashmir region for 6 days from 1 to 6 September 2014 (historical record flooding rainfall over this region).

surface temperature for all six stations mentioned. It seems that long-term (climatic) variations in the upper tropospheric vorticities have significantly less influence on surface temperature variations.

\section{Conclusions}

In this study, trends and variations in surface temperature and precipitation over the Jammu and Kashmir region (western Himalayas) of India are carried out for a period of 37 years during 1980-2016. Analyses of the observations reveal that the annual temperature increased by $0.8^{\circ} \mathrm{C}$ during this period. Higher increases in annual temperature accompanied by insignificant decreases in annual precipitation are noted for stations located at higher altitudes. Long-term variation in winter temperature and precipitation has good correlation with winter NAO index. To provide more conclusive evidence on our observations, we employed WRF model simulations, which show a good correlation of 0.85 with the ob- served data. It is found that in recent decades, precipitation associated with both the monsoons and western disturbances has been decreasing significantly. While the monsoon deficiency is associated with a decreasing difference in surface temperature between the Indian landmass and nearby Indian Ocean, the deficiency associated with western disturbances during winter is due to the climatic northward displacement of the subtropical westerly jet. This subtropical jet wind helps to enhance the moisture transport associated with disturbances from the tropical Atlantic Ocean, Mediterranean and Caspian Seas to the Himalayan region. Regarding historical extreme weather event associated with September 2014 floods in Jammu and Kashmir, it is found that the breaking of intense Rossby wave activity over Kashmir played an important role as the wave could transport lots of water vapor from both the Bay of Bengal and Arabian Sea and dump them here through its breaking during the first week of September 2014, leading to the extreme rainfall event measuring more than $620 \mathrm{~mm}$ in southern parts of the Kashmir. 
Data availability. All the observed precipitation and temperature data of India Meteorology Department (IMD), reanalysis data of ERA-interim and down-scaled model simulated data of WRF model presented in this research article are available with the lead author Sumira Nazir Zaz (zaz.sumira@gmail.com) and she can be contacted directly through her email ID or her institute address and through the second author Prof. Shakil Ahmad Romshoo (shakilrom@kashmiruniversity.ac.in and shakilrom@gmail.com), Department of Earth Sciences, University of Kashmir, Srinagar-190006, Jammu and Kashmir, India. Since the authors are not the owners of the data presented, they cannot be provided in public repositories. Ramkumar Thokuluwa Krishnamoorthy (tkram@narl.gov.in) can be contacted for any help in this regard.

Author contributions. SNZ and SAR drafted the paper with results of analyses of temperature and precipitation data. RTK made interpretations and explained the scientific reasons of observations using ERA-interim data of potential vorticities and meridional wind velocities and WRF model simulated data. YV successfully generated the WRF data for the region of Jammu and Kashmir, India, and explained how the data was generated. All the authors contributed significantly to the paper while revising the paper, taking into account of different queries of reviewers.

Competing interests. The authors declare that they have no conflict of interest.

Acknowledgements. Thanks are due to the India Meteorological Department of India, ERA-Interim reanalyses and WRF model simulation teams for the data of meteorological parameters employed in the present work. Romshoo Shakil Ahmad and Sumira Nazir Zaz gratefully acknowledge the support of the Department of Science and Technology (DST), Government of India, under the research project titled "Himalayan Cryosphere: Science and Society". Ramkumar Thokuluwa Krishnamoorthy and Yesubabu Viswanadhapalli acknowledge the support of the Department of Space, Government of India. The authors express gratitude to Hamza Varikoden, the editor and one anonymous reviewer for their valuable comments and suggestions on the earlier version of the paper that has greatly improved its content and structure.

Edited by: Jayanarayanan Kuttippurath

Reviewed by: Hamza Varikoden and one anonymous referee

\section{References}

Allen, R. J., Sherwood, S. C., Norris, J. R., and Zender, C. S.: Recent Northern Hemisphere tropical expansion primarily driven by black carbon and tropospheric ozone, Nature, 485, 350-354, https://doi.org/10.1038/nature11097, 2012.

Archer, D. R. and Fowler, H. J.: Spatial and temporal variations in precipitation in the Upper Indus Basin, global teleconnections and hydrological implications, Hydrol. Earth Syst. Sci., 8, 47-61, https://doi.org/10.5194/hess-8-47-2004, 2004.
Barnes, E. A. and Polvani, L.: Response of the mid latitude jets, and of their variability, to increased greenhouse gases in the CMIP5 models, J. Climate, 26, 7117-7135, https://doi.org/10.1175/JCLI-D-12-00536.1, 2013.

Barnes, E. A., Solomon, S., and Polwani, L. M.: Robust wind and precipitation responses to the Mount Pinatubo eruption, as simulated in the CMIP5 Models, J. Climate, 29, 4763-4778, https://doi.org/10.1175/JCLI-D-15-0658.1, 2016.

Bartels, J., Peters, D., and Schmitz, G.: Climatological Ertel's potential-vorticity flux and mean meridional circulation in the extratropical troposphere - lower stratosphere, Ann. Geophys., 16, 250-265, https://doi.org/10.1007/s00585-998-0250-3, 1998.

Beniston, M.: Impact of climatic change on water and associated economic activities in the Swiss Alps, J. Hydrol., 412-413, 291296, https://doi.org/10.1016/j.jhydrol.2010.06.046, 2010.

Bhutiyani, M. R., Kale, V. S., and Pawar, N. J.: Long-term trends in maximum, minimum and mean annual air temperatures across the north western Himalaya during the 20th century, Clim. Change, 85, 159-177, 2007.

Bhutiyani, M. R., Kale, V. S., and Pawar, N. J.: Climate change and the precipitation variations in the north western Himalaya: 18662006, Int. J. Climatol., 30, 535-548, 2009.

Bhutiyani, M. R., Kale, V. S., and Pawar, N. J.: Climate change and the precipitation variations in the north western Himalaya: 18662006, Int. J. Climatol., 30, 535-548, 2010.

Bolch, T., Kulkarni, A., and Kaabet, A.: The state and fate of Himalayan glaciers, Science, 336, 310-314, 2012.

Bookhagen, B.: Appearance of extreme monsoonal rainfall events and their impact on erosion in the Himalaya, Geomatics, Natural Hazards and Risk, 1, 37-50, https://doi.org/10.1080/19475701003625737, 2010.

Borgaonkar, H. P. and Pant, G. B.: Long-term climate variability over monsoon Asia as revealed by some proxy sources, Mausam, 52, 9-22, 2001.

Ceppi, P., Zelinka, M. D., and Hartmann, D. L.: The response of the southern hemispheric eddy-driven jet to future changes in shortwave radiation in CMIP5, Geophys. Res. Lett., 41, 3244-3250, https://doi.org/10.1002/2014GL060043, 2014.

Chang, E. K. M. and Yu, D. B.: Characteristics of Wave Packets in the Upper Troposphere. Part I: Northern Hemisphere Winter, J. Atmos. Sci., 56, 1708-1728, 1999.

Chen, F. and Dudhia, J.: Coupling an advanced landsurface/hydrology model with the Penn State/NCAR MM5 modeling system. Part I: Model description and implementation, Mon. Weather Rev., 129, 569-585, https://doi.org/10.1175/15200493(2001)129<0569:CAALSH>2.0.CO;2, 2001.

Chen, J. and Gupta, A. K.: Parametric Statistical Change Point Analysis, Birkhauser, Boston, MA, 240, 2012.

Coumou, D., Petoukhov, V., Rahmstorf, S., Petri, S., and Schellnhuber, H. J.: Quasi-resonant circulation regimes and hemispheric synchronization of extreme weather in boreal summer, P. Natl. Acad. Sci. USA, 111, 12331-12336, https://doi.org/10.1073/pnas.1412797111, 2014.

Dar, R. A., Romshoo, S. A., Chandra, R., and Ahmad, I.: Tectonogeomorphic study of the 4 Karewa Basin of Kashmir valley, J. Asian Earth Sci., 92, 143-156, 2014.

Das, M. R., Mukhopadhyay, R. L., Dandekar, M. M., and Kshirsagar, S. R.: Pre-monsoon western disturbances in relation to 
monsoon rainfall, its advancement over NW India and their trends, Curr. Sci. India, 82, 1320-1321, 2002.

Dee, D. P., Uppala, S. M., Simmons, A. J., Berrisford, P., Poli, P., Kobayashi, S., Andrae, U., Balmaseda, M. A., Balsamo, G., Bauer, P., Bechtold, P., Beljaars, A. C. M., van de Berg, L., Bidlot, J., Bormann, N., Delsol, C., Dragani, R., Fuentes, M., Geer, A. J., Haimberger, L., Healy, S. B., Hersbach, H., Hólm, E. V., Isaksen, L., Kållberg, P., Köhler, M., Matricardi, M., McNally, A. P., Monge-Sanz, B. M., Morcrette, J.-J., Park, B. K., Peubey, C., de Rosnay, P., Tavolato, C., Thépaut, J.-N., and Vitart, F.: The ERA-Interim reanalysis: configuration and performance of the data assimilation system, Q. J. R. Meteorol. Soc., 137, 553-597, https://doi.org/10.1002/qj.828, 2011.

Dimri, A. P. and Dash, S. K.: Winter time climatic trends in the western Himalayas, Clim. Change, 111, 775-800, 2012.

Dudhia, J.: Numerical study of convection observed during the winter monsoon experiment using a mesoscale twodimensional model, J. Atmos. Sci., 46, 3077-3107 https://doi.org/10.1175/15200469(1989)046<3077:NSOCOD>2.0.CO;2, 1989.

Edmon, H. J., Hoskins, B. J., and McIntyre, M. E.: Eliassen-Palm cross sections for the troposphere, J. Atmos. Sci., 37, 2600-2615, 1980.

Ertel, H.: Ein neuer hydrodynamischer Wirbelsatz, Meteor. Z., 59, 277-281, 1942.

Folland, C. K., Rayner, N. A., Brown, S. J., Smith, T. M., Shen, S. P., Parker, D. E., Macadam, I., Jones, P. D., Nicholls, R. N. N., and Sexton, D. M. H.: Global temperature change and its uncertainties since 1861, Geophys. Res. Let., 28, 2621-2624, https://doi.org/10.1029/2001GL012877, 2001.

Fowler, H. J. and Archer, D. R.: Conflicting signals of climatic change in the Upper Indus Basin, J. Climate, 19, 4276-4293, 2006.

Gao, P., Mu, X.-M., Wang, F., and Li, R.: Changes in streamflow and sediment discharge and the response to human activities in the middle reaches of the Yellow River, Hydrol. Earth Syst. Sci., 15, 1-10, https://doi.org/10.5194/hess-15-1-2011, 2011.

Garfinkel, C. I. and Waugh, D. W.: Tropospheric Rossby wave breaking and variability of the latitude of the eddy-driven jet, J. Climate, 27, 7069-7085, https://doi.org/10.1175/JCLI-D-14$00081.1,2014$.

Ghasemi, A. R.: Changes and trends in maximum, minimum and mean temperature series in Iran, Atmos. Sci. Lett., 16, 366-372, https://doi.org/10.1002/asl2.569, 2015.

Groisman, P. Y., Karl, T. R., Knight, R. W., and Stenchikov, G. L.: Changes of snow cover, temperature, and radiative heat balance over the northern hemisphere, J. Climate, 7, 1633-1656, https://doi.org/10.1175/15200442(1994)007<1633:COSCTA>2.0.CO;2, 1994.

Hansen, A. R., Nastrom, G. D., and Eaton, F. D.: Seasonal variation of gravity wave activity at 5-20 km observed with VHF radar at White Sands Missile Range, New Mexico, J. Geophys. Res., 106, 17171-17183, https://doi.org/10.1029/2001JD900137, 2001.

Hijioka, Y., Lin, E., Pereira, J. J., Corlett, R. T., Cui, X., Insarov, G. E., Lasco, R. D., Lindgren, E., and Surjan, A.: Asia, in: Climate Change 2014: Impacts, Adaptation, and Vulnerability. Part B: Regional Aspects. Contribution of Working Group II to the Fifth Assessment Report of the Intergovernmental Panel of Climate Change, edited by: Barros, V. R., Field, C. B., Dokken, D.
J., Mastrandrea, M. D., Mach, K. J., Bilir, T. E., Chatterjee, M., Ebi, K. L., Estrada, Y. O., Genova, R. C., Girma, B., Kissel, E. S., Levy, A. N., MacCracken, S., Mastrandrea, P. R., and White, L. L., Cambridge University Press, Cambridge, United Kingdom and New York, NY, USA, 2014.

Homeyer, C. R. and Bowman, K. P.: Rossby Wave Breaking and Transport between the Tropics and Extratropics above the Subtropical Jet, J. Atmos. Sci., 70, 607-626, https://doi.org/10.1175/JAS-D-12-0198.1, 2013.

Hong, S. H., Noh, Y., and Dudhia, J.: A new vertical diffusion package with an explicit treatment of entrainment processes, Mon. Weather Rev., 134, 2318-2341, https://doi.org/10.1175/MWR3199.1, 2006.

Hoskins, B. J., Simmons, A. J., and Andrews, D. G.: Energy dispersion in a barotropic atmosphere, Q. J. Roy. Meteor. Soc., 103, 553-567, 1977.

Hoskins, B. J., McIntyre, M. E., and Robertson, A. W.: On the use and significance of isentropic potential vorticity maps, Q. J. Roy. Meteor. Soc., 111, 877-946, 1985.

Hunt, K. M. R., Turner, A. G., and Shaffrey, L. C.: Extreme daily rainfall in Pakistan and north India: scale-interactions, mechanisms, and precursors, Mon. Weather Rev., 146, 1005-1022, https://doi.org/10.1175/MWR-D-17-0258.1, 2018a.

Hunt, K. M. R., Turner, A. G., and Shaffrey, L. C.: The evolution, seasonality and impacts of western disturbances, Q. J. Roy. Meteor. Soc., 144, 278-290, https://doi.org/10.1002/qj.3200, 2018b.

Hurrell, J. W. and van Loon, H.: Decadal variations in climate associated with the North Atlantic Oscillation, Clim. Change, 36, 301-326, Res. Lett., 23, 665-668, 1997.

Immerzeel, W., Van Beek, L. P. H., and Bierkens, M. F. P.: Climate change will affect the Asian water towers, Science, 328, 13821385, 2010.

IPCC: Climate change (2001), Impacts, adaption and vulnerability. Contribution of Working Group II to the Third Assessment Report of the Intergovernmental Panel of Climate Change, Intergovernmental Panel on Climate Change, Cambridge, UK, 2001.

IPCC: Climate Change 2013, in: The Physical Science Basis. Contribution of Working Group I to the Fifth Assessment Report of the Intergovernmental Panel on Climate Change, edited by: Stocker, T. F., Qin, D., Plattner, G.-K., Tignor, M., Allen, S. K., Boschung, J., Nauels, A., Xia, Y., Bex, V., Midgley, P. M., Cambridge University Press, Cambridge, United Kingdom and New York, NY, USA, 1535, 2013.

Iqbal, M. J. and Kashif, I.: Influence of Icelandic Low pressure on winter precipitation variability over northern part of Indo-Pak Region Arabian, J. Geosci., 6, 543-548, https://doi.org/10.1007/s12517-011-0355-y, 2013.

Jones, P. D., Osborn, T. J., and Briffa, K. R.: The evolution of climate over the last millennium, Science, 292, 662-667, 2001.

Kain, J. S.: The Kain-Fritsch convective parameterization: an update, J. Appl. Meteorol., 43, 170-181, 2004.

Kain, J. S. and Fritsch, J. M.: A One-dimensional entraining/detraining plume model and its application in convective parameterization, J. Atmos. Sci., 47, 2784-2802, 1990.

Kain, J. S. and Fritsch, J. M.: Convective parameterization for mesoscale models: The Kain-Fritsch scheme, in: The Representation of Cumulus Convection in Numerical Models, edited by: Emanuel, K. A. and Raymond, D. J., American Me- 
teorological Society, Meteorological Monographs, 46, 1-246, https://doi.org/10.1175/0065-9401-24.46.1, 1993.

Kaul, V. and Qadri, B. A.: Seasons of Kashmir, Geographic Revison India, 41, 123-130, 1979.

Khattak, M. S., Babel M. S., and Sharif, M.: Hydro-meteorological trends in the upper Indus River basin in Pakistan, Inter-Research, Clim. Res., 46, 103-119, https://doi.org/10.3354/cr00957, 2011.

Knutti, R., Rogelj, J., Sedláček, J., and Fischer, E. M.: A scientific critique of the two-degree climate change target, Nat. Geosci., 9, 13-18, 2016.

Kohler, T. and Maselli, D.: Mountains and climate change from understanding to action, Swiss Agency for Development and Cooperation, Berne, 2009.

Kulkarni, A. V., Mathur, P., Rathore, B. P., Suja, A., Thakur, N., and Manoj, K.: Effect of global warming on snow ablation pattern in the Himalaya, Curr. Sci. India, 83, 120-123, 2002.

Kumar, N., Yadav, B. P., Gahlot, S., and Singh, M.: Winter frequency of western disturbances and precipitation indices over Himachal Pradesh, India: 1977-2007, Atmósfera, 28, 63-70, https://doi.org/10.1016/S0187-6236(15)72160-0, 2015.

Kumar, V. and Jain, S. K.: Trends in seasonal and annual rainfall and rainy days in Kashmir valley in the last century, Quatern. Int., 212, 64-69, https://doi.org/10.1016/j.quaint.2009.08.006, 2010.

Kunz, T., Fraedrich, K., and Lunkeit, F.: Response of idealized baroclinic wave life cycles to stratospheric flow conditions, J. Atmos. Sci., 66, 2288-2302, https://doi.org/10.1175/2009JAS2827.1, 2009.

Langodan, S., Yesubabu, V., and Hoteit, I.: The impact of atmospheric data assimilation on wave simulations in the Red Sea, Ocean Eng., 116, 200-215, https://doi.org/10.1016/j.oceaneng.2016.02.020, 2016.

Liu, X., Cheng, Z., Yan, L., and Yin, Z. Y.: Elevation dependency of recent and future minimum surface air temperature trends in the Tibetan Plateau and Its surroundings, Global Planet Change, 68, 164-174, 2009.

Liu, X. B. and Chen, B.: Climatic warming in the Tibetan Plateau during recent decades, J. Climate, 20, 1729-1742, 2000.

Lo, J. C. F., Yang, Z. L., and Pielke Sr., R. A.: Assessment of three dynamical climate downscaling methods using the weather research and forecasting (WRF) model, J. Geophys. Res., 113, D09112, https://doi.org/10.1029/2007JD009216, 2008.

Lu, J., Sun, L., Wu, Y., and Chen, G.: The role of subtropical irreversible PV mixing in the zonal mean circulation response to global warming-like thermal forcing, J. Climate, 27, 2297-2316, https://doi.org/10.1175/JCLI-D-13-00372.1, 2014.

Madala, S., Satyanarayana, A. N. V., and Narayana Rao, T.: Performance evaluation of PBL and cumulus parameterization schemes of WRF ARW model in simulating severe thunderstorm events over Gadanki MST radar facility - Case study, Atmos. Res., 139, 1-17, https://doi.org/10.1016/j.atmosres.2013.12.017, 2014.

Madhura, R. K., Krishnan, R., Revadekar, J. V., Mujumdar, M., and Goswami, B. N.: Changes in western disturbances over the Western Himalayas in a warming environment, Clim. Dynam., 44, 1157-1168, https://doi.org/10.1007/s00382-014-2166-9, 2015.

Mann, M. E., Bradley, R. S., and Hughes, M. K.: Northern Hemisphere Temperature During Past Millennium: Inferences, uncertainties and Limitations, Geophys. Res. Lett., 26, 759-762, 1999.

Martius, O., Sodemann, H., Joos, H., Pfahl, S., Winschall, A., Croci-Maspoli, M., Graf, M., Madonna, E., Mueller, B.,
Schemm, S., Sedlaćek, J., Sprenger, M., and Wernli, H.: The role of upper-level dynamics and surface processes for the Pakistan flood of July 2010, Q. J. Roy. Meteor. Soc., 139, 1780-1797, https://doi.org/10.1002/qj.2082, 2012.

McIntyre, M. E. and Palmer, T. N.: Breaking planetary waves in the stratosphere, Nature, 305, 593-600, 1983.

Meehl, G. A., Covey, C., Delworth, T., Latif, M., McAvaney, B., Mitchell, J. F. B., Stouffer, R. J., and Taylor, K. E.: The WRCP CMIP3 multi-model dataset: A new era in climate change research, B. Am. Meteorol. Soc., 88, 1383-1394, 2007.

Mlawer, E. J., Taubnam, S. J., Brown, P. D., Iacono, M. J., and Clough, S. A.: Radiative transfer for inhomogeneous atmospheres: RRTM, a validated correlated-k model for the longwave, J. Geophys. Res., 102, 16663-16682, https://doi.org/10.1029/97JD00237, 1997.

Mooley, D. A. and Parthasarthy, B.: Fluctuations of all India summer monsoon rainfall during 1871-1978, Clim. Change, 6, 287$301,1984$.

Murtaza, K. O. and Romshoo, S. A.: Recent Glacier Changes in the Kashmir Alpine Himalayas, India, Geocarto International, 32, 188-205, 2016.

Nibanupudi, H. K., Gupta, A. K., and Rawat, P. K.: Mountain Hazards and Disaster Risk (2015): Mitigating Climatic and Human Induced Disaster Risks Through Ecosystem Resilience: Harmonizing Built and Natural Environments in the KHK Region, edited by: Nibanupudi, H. K. and Shaw, R., Springer, Tokyo, Japan, 139-158, https://doi.org/10.1007/978-4431-55242-0, 2015.

Niranjan Kumar, K., Phanikumar, D. V., Ouarda, T. B. M. J., Rajeevan, M., Naja, M., and Shukla, K. K.: Modulation of surface meteorological parameters by extratropical planetary-scale Rossby waves, Ann. Geophys., 34, 123-132, https://doi.org/10.5194/angeo-34-123-2016, 2016.

Ogura, Y. and Yoshizaki, M.: Numerical study of orographic convective precipitation over the eastern Arabian Sea and the Ghat Mountains during the summer monsoon, J. Atmos. Sci., 45, 2097-2122, 1988.

Peters, G. P., Andrew, R. M., Boden, T., Canadell, J. G., Ciais, P., Le Quéré, C., Marland, G., Raupach, M. R., and Wilson, C.: The challenge to keep global warming below $2{ }^{\circ} \mathrm{C}$, Nature, Clim. Change, 3, 4-6, https://doi.org/10.1038/nclimate1783, 2013.

Petoukhov, V., Rahmstorf, S., Petri, S., and Schellnhuber, H. J.: Quasi resonant amplification of planetary waves and recent Northern Hemisphere weather extremes, P. Natl. Acad. Sci. USA, 110, 5336-5341, 2013.

Pettitt, A. N.: A non-parametric approach to the change point problem, App. Stats., 28, 126-135, 1979.

Postel, G. A. and Hitchman, M. H.: Climatology of Rossbywave breaking along the subtropical tropopause, J. Atmos. Sci., 56, 359-373, 1999.

Priyanka, G., Ramkumar, T. K., Yesubabu, V., and Naidu, C. V.: Convection-generated high-frequency gravity waves as observed by MST radar and simulated by WRF model over the Indian tropical station of Gadanki, Q. J. Roy. Meteor. Soc., 142, 3036-3049, https://doi.org/10.1002/qj.2887, 2016.

Radziejewski, M., Bardossy, A., and Kundzewicz, Z. W.: Detection of change in river flow using phase randomization, Hydrol. Sci. J., 45, 547-558, 2000. 
Rashid, I., Romshoo, A. S., Chaturvedi, R. K., Ravindranath, N. H., Raman Sukumar, Mathangi Jayaraman, Thatiparthi Vijaya Lakshmi, and Jagmohan Sharma: Projected Climate Change Impacts on Vegetation Distribution over Kashmir Himalaya, Clim. Change, 132, 601-613, https://doi.org/10.1007/s10584015-1456-5, 2015.

Rasmussen, K. L. R. and Houze, R.: A Flash-Flooding Storm At The Steep Edge Of High Terrain: Disaster in the Himalayas, B. Am. Meteorol. Soc., 93, 1713-1724, https://doi.org/10.1175/BAMS-D-11-00236.1, 2012.

Rasmussen, K. L. and Houze Jr., R. A.: Convective initiation near the Andes in subtropical South America, Mon. Weather Rev., 144, 2351-2374, https://doi.org/10.1175/MWRD-15-0058.1, 2016.

Rienecker, M. M., Suarez, M. J., Gelaro, R., Todling, R., Bacmeister, J., Liu, E., Bosilovich , M. G., Schubert, S. D., Takacs, L., Kim, G.-K., Bloom, S., Chen, J., Collins, D., Conaty, A., da Silva, A., Gu, W., Joiner, J., Koster, R. D., Lucchesi, R., Molod, A., Owens, T., Pawson, S., Pegion, P., Redder, C. R., Reichle, R., Robertson, F. R., Ruddick, A. G., Sienkiewicz, M., and Woollen, J.: MERRA: NASA's Modern-Era Retrospective Analysis for Research and Applications, J. Climate, 24, 3624-3648, https://doi.org/10.1175/JCLI-D-11-00015.1, 2011.

Rivière, G.: A dynamical interpretation of the poleward shift of the jet streams in global warming scenarios, J. Atmos. Sci., 68, 1253-1272, https://doi.org/10.1175/2011JAS3641.1, 2011.

Roe, G. H., Montgomery, D. R., and Hallet, B.: Orographic climate feedbacks and the relief of mountain ranges, J. Geophys. Res., 108, 108, 2315-2327, https://doi.org/10.1029/2001JB001521, 2003.

Romatschke, U. and Houze, R.: Characteristics of Precipitating Convective Systems in the Premonsoon Season of South Asia, J. Hydrometeorol., 12, 157-180, https://doi.org/10.1175/2010JHM1311.1, 2011.

Romshoo, S. A. and Rashid, I.: Assessing the impacts of changing land cover and climate on Hokersar wet land in Indian Himalayas, Arab. J. Geosci., 7, 143-160, https://doi.org/10.1007/s12517-012-0761-9, 2014.

Romshoo, S. A., Dar, R. A., Rashid, I., Marazi, A., Ali, N., and Zaz, S. N.: Implications of Shrinking Cryosphere under Changing Climate on the Stream flows of the Upper Indus Basin, Arct. Antarct. Alp. Res., 47, 627-644, 2015.

Romshoo, S. A., Altaf, S., Rashid, I., and Dar, R. A.: Climatic, geomorphic and anthropogenic drivers of the 2014 extreme flooding in the Jhelum basin of Kashmir, India, Geomatics, Natural Hazards and Risk, 9, 224-248, 2017.

Schubert, S., Wang, H., and Suarez, M.: Warm season subseasonal variability and climate extremes in the Northern Hemisphere: The Role of Stationary Rossby Waves, J. Climate, 24, 47734792, 2011.

Screen, J. A. and Simmonds, I.: Amplified mid-latitude planetary waves favour particular regional weather extremes, Nat. Clim. Change, 4, 704-709, 2014.

Sharif, M., Archer, D. R., Fowler, H. J., and Forsythe, N.: Trends in timing and magnitude of flow in the Upper Indus Basin, Hydrol. Earth Syst. Sci., 17, 1503-1516, https://doi.org/10.5194/hess-171503-2013, 2013.

Sheikh, M. M., Manzoor, N., Adnan, M., Ashraf, J., and Khan, A. M.: Climate Profile and pastclimate changes in Pakistan GCISC-
RR-01Global Change Impact studies Center Islamabad, Pakistan, ISBN: 978-969-9395-04, 2009.

Shekhar, M. S., Chand, H., Kumar, S., and Ganju, A.: Climate change studies in western Himalaya, Ann. Glaciol., 51, 105-112, 2010.

Shrestha, A. B., Wake, C. P., Dibb, J. E., and Mayewski, P. A: Precipitation fluctuations in the Nepal Himalaya and its vicinity and relationship with some large scale climatological parameters, Int. J. Climatol., 20, 317-327, 1999.

Shrestha, M. L.: Interannual variation of summer monsoon rainfall over Nepal and its relation to Southern Oscillation Index, Meteor. Atmos. Phys., 75, 21-28, https://doi.org/10.1007/s007030070012, 2000.

Sinha Ray, K. C. and Srivastava, A. K.: Is there any change in extreme events like drought and heavy rainfall?, Curr. Sci. India, 79, 155-158, 2000.

Solomon, S., Qin, D., Manning, M., Chen, Z., Marquis, M., Averyt, K. B., Tignor, M., and Miller, H. L. (Eds.): Climate change 2007: the physical science basis, Contribution of Working Group I to the Fourth Assessment Report of the Intergovernmental Panel on Climate Change Cambridge University Press, Cambridge, United Kingdom and New York, NY, USA, 996 pp., 2007.

Srinivas, C. V., Hariprasad, D., Bhaskar Rao, D. V., Anjaneyulu, Y., Baskaran, R., and Venkatraman, B.: Simulation of the Indian summer monsoon regional climate using advanced research WRF model, Int. J. Climatol., 33, 1195-1210. https://doi.org/10.1002/joc.3505, 2013.

Srinivas, C. V., Yesubabu, V., Hari Prasad, D., Hari Prasad, K. B. R. R., Greeshmaa, M. M., Baskarana, R., and Venkatramana, B.: Simulation of an extreme heavy rainfall event over Chennai, India using WRF: Sensitivity to grid resolution and boundary layer physics, Atmos. Res., 210, 66-82, https://doi.org/10.1016/j.atmosres.2018.04.014, 2018.

Swanson, D., Wooten, K., and Orr, T.: Buckets of ash track tephra flux from Halema'uma'u crater, Hawai'i, Eos Trans., AGU, 90, 427-428, 2009.

Syed, F. S., Giorgi, F., Pal, J. S., and King, M. P.: Effect of remote forcings on the winter precipitation of central southwest Asia part 1: observations, Theor. Appl. Climatol., 86, 147-160, https://doi.org/10.1007/s00704-005-0217-1, 2006.

Tandon, N. F., Gerber, E. P., Sobel, A. H., and Polvani, L. M.: Understanding Hadley cell expansion versus contraction: Insights from simplified models and implications for recent observations, J. Climate, 26, 4304-4321, https://doi.org/10.1175/JCLI-D-12$00598.1,2013$.

Thompson, L. G., Mosley-Thompson, E., Davis, M. E., Lin, P. N., Henderson, K., and Mashiotta, T. A.: Tropical glacier and ice core evidence of climate change on annual to millennial time scales, Clim. Change, 59, 137-155, 2003.

Viswanadhapalli, Y., Dasari, H. P., Langodan, S., Challa, V. S., and Hoteit, I.: Climatic features of the Red Sea from a regional assimilative model. Int. J. Climatol., 37, 2563-2581, https://doi.org/10.1002/joc.4865, 2017.

Vose, R. S., Easterling, D. R., and Gleason, B.: Maximum and minimum temperature trends for the globe: an update through 2004, Geophys. Res. Lett., 32, 1-5, 2005.

Waugh, D. W. and Polvani, L. M.: Climatology of intrusions in to the tropical upper troposphere, Geophys. Res. Lett., 27, 38573860, 2000. 
Wilcox, L. J., Charlton-Perez, A., and Gray, L. J.: Trends in austral jet position in ensembles of high-and lowtop CMIP5 models, J. Geophys. Res., 117, D13115, https://doi.org/10.1029/2012JD017597, 2012.

Wiltshire, A. J.: Climate change implications for the glaciers of the Hindu Kush, Karakoram and Himalayan region, The Cryosphere, 8, 941-958, https://doi.org/10.5194/tc-8-941-2014, 2014.

Wittman, M. A., Charlton, A. J., and Polvani, L. M.: The effect of lower stratospheric shear on baroclinic instability, J. Atmos. Sci., 64, 479-496, https://doi.org/10.1175/JAS3828.1, 2007.
World Meteorological Organization: Guide to Meteorological practices, 2nd edn., WMO No 168, Tech Paper, 82, Geneva, Switzerland, 1970.

Yunling, H. and Yiping, Z.: Climate change from 1960-2000 in the Lancang River Valley, China, Mt. Res. Dev., 25, 341-348, 2005.

Zarenistana, K. M., Dhorde, A. G., and Kripalani, R. H.: Temperature analysis over southwest Iran: trends and projections, Theor. Appl. Climatol., 116, 103-117, 2014. 